\title{
DNA methyltransferase enzymes (MTases) may not enhance genomic protection against exogenous DNA invasions
}

by

Sanoji Wijenayake

A thesis submitted to the Faculty of Graduate and Postdoctoral Affairs in partial fulfillment of the requirements for the degree of

\author{
Masters of Science \\ in \\ Biological Science
}

Carleton University

Ottawa, Ontario

2012

Sanoji Wijenayake 
Library and Archives

Canada

Published Heritage

Branch

395 Wellington Street

Ottawa ON K1A ON4

Canada
Bibliothèque et

Archives Canada

Direction du

Patrimoine de l'édition

395 , rue Wellington

Ottawa ON K1A ON4

Canada
Your file Votre référence

ISBN: 978-0-494-93533-0

Our file Notre référence

ISBN: 978-0-494-93533-0
NOTICE:

The author has granted a nonexclusive license allowing Library and Archives Canada to reproduce, publish, archive, preserve, conserve, communicate to the public by telecommunication or on the Internet, loan, distrbute and sell theses worldwide, for commercial or noncommercial purposes, in microform, paper, electronic and/or any other formats.

The author retains copyright ownership and moral rights in this thesis. Neither the thesis nor substantial extracts from it may be printed or otherwise reproduced without the author's permission.
AVIS:

L'auteur a accordé une licence non exclusive permettant à la Bibliothèque et Archives Canada de reproduire, publier, archiver, sauvegarder, conserver, transmettre au public par télécommunication ou par l'Internet, prêter, distribuer et vendre des thèses partout dans le monde, à des fins commerciales ou autres, sur support microforme, papier, électronique et/ou autres formats.

L'auteur conserve la propriété du droit d'auteur et des droits moraux qui protege cette thèse. $\mathrm{Ni}$ la thèse ni des extraits substantiels de celle-ci ne doivent être imprimés ou autrement reproduits sans son autorisation.
In compliance with the Canadian Privacy Act some supporting forms may have been removed from this thesis.

While these forms may be included in the document page count, their removal does not represent any loss of content from the thesis.
Conformément à la loi canadienne sur la protection de la vie privée, quelques formulaires secondaires ont été enlevés de cette thèse.

Bien que ces formulaires aient inclus dans la pagination, il n'y aura aucun contenu manquant. 


\begin{abstract}
DNA methylation is thought to function as a host-driven response against extracellular invaders in all three domains of life. Here I devise and test an alternative hypothesis, the transposonmediated immunity hypothesis, that gene regulation via DNA methylation originated in ancestral eubacteria as a transposon-mediated countermeasure to endonuclease cleavage. I predict that transposon-coded proteins may have influenced eubacterial DNMTases into hypermethylating eubacterial restriction endonuclease sites, decreasing endonuclease enzyme's accessibility to palindromic sequences and rendering $\mathrm{rm}$ system II ineffective at removing transposable elements from the genome.
\end{abstract}




\section{Acknowledgements}

I would like to thank Dr. Root Gorelick for giving me the opportunity to finish my master's under his supervision. Thank you for always being patient and understanding whenever I proposed a wacky research idea. I know at times we have had very different viewpoints on evolution and on the empirical aspect of science, but you always trusted my judgment (even when you did not agree with it) and allowed me to make independent decisions about my thesis. This helped transform me into the researcher I am today.

I would like to thank Danielle Fraser, my good friend and colleague in the Gorelick lab, for the countless hours of discussions and insights on the phylogenetic comparative method. Dani, you taught me how to write algorithms for $\mathrm{R}$ and most importantly taught me how to trouble shoot and not be intimidated by $\mathrm{R}$. You are one of the most driven scientific researchers I have ever met and you aspire me to become a better researcher on a daily basis. I would also like to thank Zoe Panchen and Lindsay Derraugh for the advice and support.

I would like to sincerely, thank Dr. Tom Sherratt and each person in the Sherratt lab. Chris, you are simply the BEST, thank you for always willing to help me with just about everything, I know that you are just a text, email, phone call, or six hour plane ride away. Bells, Tom $\mathrm{H}$, Kevin, Rich and Jennette, you have made the last two years the best graduate experience, and I know once I leave here, I will not only have six colleagues, but six really good friends.

Most importantly, I would like to thank my family, my dad, mum, Aiyya and Akki. Ammi and Thathi, you two are the reason why I am finishing my master's today and going on to complete a PhD in Biology. I could not have wished for two better people to call my mum and dad. Thank you for always loving and supporting me through everything. You two are and have always been 
my biggest fans and I know regardless I succeed or fail in whatever I do, you will be proud of me. Akki, I am soo glad that I have a sister like you. I can count on for everything in life and I do not know how I will get through the day without you, I love you to death. Aiyya thank you for the sibling competition. Trying to compete with you is like running with a cheetah, it is very hard to keep up.

Thank you to my besties, Supun, Spojmai and Uzma. You three are my shadows. I know that I can count on you to laugh, cry, fight or even cover up a murder if need be. Thank you to all my other amazing friends and all my cousins (especially Nad) for your constant support, well wishes and love. I am very lucky to have all of you in my life!

Last but not least, thank you to my partner in crime, Tharanga. I love you more than words can say. Thank you for being my corner stone! I cannot wait to spend the rest of my life with you. 


\section{Contributions:}

Dr. Chris Hassel and I worked on the algorithm for $\mathrm{R}$ to assign species-specific, sequence probes that correspond to the endonuclease restriction and methylase sequences for the 68 -eubacterial species.

Dani Fraser and I worked closely on the phylogenetic comparative method in $\mathrm{R}$ to correlate the total number of endonuclease restriction to the methylase sites. 


\section{Table of Contents}

Acknowledgements.....

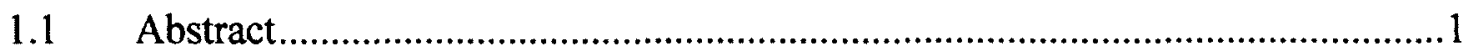

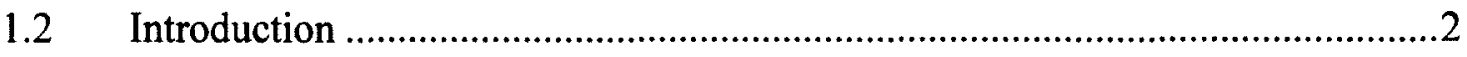

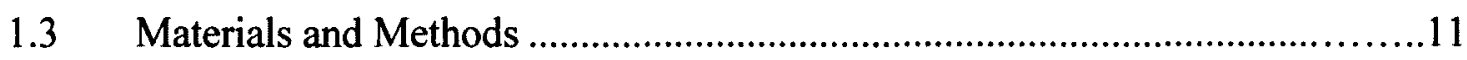

Sequence comparison...........................................11

Phylogenetic construction .....................................13

Phylogenetic signal..........................................13

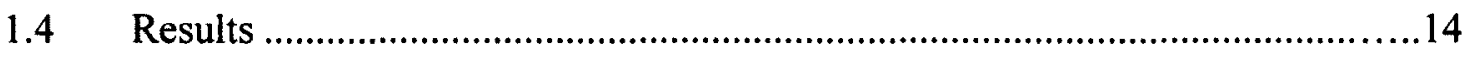

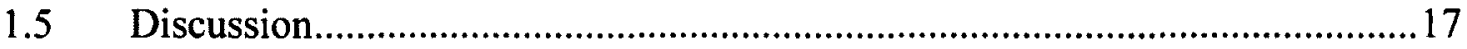

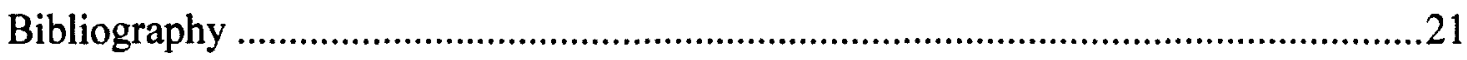

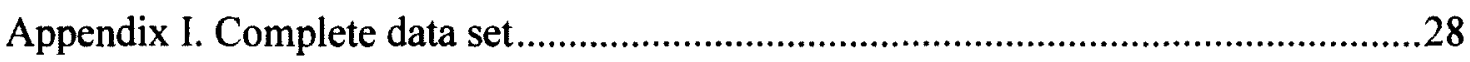

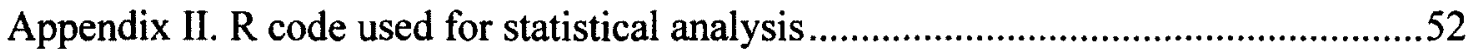

Pagel's lambda phylogenetic signal..............................11

Quantitative sequence search .................................13

Appendix III. Molecular phylogeny based on 16S rRNA .......................................62 


\section{List of Tables}

Table

Title

Page

1 Total number of type II endonuclease restriction sites, number of methylase

15 sites, and number of overlapping sites in 16s rRNA genomes of 40 microbial species in 23 families.

228 microbial species with zero endonuclease and methylase sites in the $16 \mathrm{~S}$

16 rRNA gene loci.

S1 Restriction sequences of 344 type II endonuclease enzymes and 212 type II methyltransferases, belonging to 261 microbial species.

S2 NCBI GenBank accession numbers for 16s rRNA, type II restriction endonuclease restriction enzymes and respective palindromic restriction sites, methylase enzymes and respective methylase sites for all 68 species.

S3 Number of endonuclease restriction sequences, number of methylase sequences, and number of overlapping sequences of 96 type II restriction endonuclease enzymes and 96 corresponding methylase enzymes in 40 microbial species. 


\section{List of Figures:}

Figure

Title

Page

1 Three main types of covalently methylated nitrogenous base products.

2 Alternative forms of DNA methylation.

3

Methylation of palindromic recognition sites prevents systematic

11 cleavage of transposons by EcoRI.

4

Molecular phylogeny of 38 eubacterial and 2 archaeabacterial species

62 based on complete and partial 16S rRNA. 


\section{List of Appendices:}

Appendix

Title

Page

I

Complete data set

S1. Restriction sequences of 344 type II endonuclease enzymes and 466 methylase sequences of 212 type II methyltransferases, belonging to 261 microbial species.

S2. NCBI GenBank accession numbers for 16s rRNA, type II restriction endonuclease restriction enzymes and respective palindrome restriction sites, methylase enzymes and respective methylase sites for all 68 species.

S3. Number of endonuclease restriction sequences, number of methylase sequences, and number of overlapping sequences of 96 type II restriction endonuclease enzymes and 96 corresponding methylase enzymes in 68 microbial species.

II $\quad \mathrm{R}$ code used for statistical analysis

Pagel's lambda phylogenetic signal

Quantitative sequence search 


\section{Abstract}

DNA methylation is an epigenetic signal that regulates gene expression. The main hypothesis concerning its origin, the genomic autoimmunity hypothesis, claims that DNA methylation arose as a host-driven response against extracellular invaders. Here I devise and test a novel hypothesis, the transposon-mediated immunity hypothesis, that gene regulation via DNA methylation originated in ancestral eubacteria as a transposon-mediated countermeasure to endonuclease cleavage. I predict that transposon-coded proteins may have influenced eubacterial DNMTases into hypermethylating eubacterial restriction endonuclease sites, decreasing endonuclease enzyme's accessibility to palindromic sequences and rendering rm system II ineffective at removing transposable elements from the genome. To test this hypothesis, I compared 666 palindromic endonuclease recognition sequences to 466 methylase sequences of restriction modification system II in 262 eubacterial and archaeabacterial species. Furthermore, I analyzed $16 \mathrm{~S}$ ribosomal RNA for 40 microbial species belonging to 23 families to quantify the number of methylated restriction sites in each microbial genome. I built a phylogeny based on 16S rRNA and tested for phylogenetic dependence using Pagel's lambda ( $\lambda$ ). I found that endonuclease restriction sequences overlap with the corresponding methylase sequences $100 \%$ of the time. This result is consistent with my hypothesis that type II restriction enzymes experience "cognate" methylation (methylation that is conferred by the species-specific DNMTases) and result in the incomplete formation of enzyme-substrate complex between the restriction enzymes and their recognition sites. Hypermethylation of restriction sites by DNMTases seem to render rm system II ineffective at removing exogenous DNA from the genomes of eubacteria and archaeabacteria. 


\section{Introduction}

DNA methylation is a chemically stable covalent modification of cytosine (Razin and Riggs 1980; Wolffe Matzke 1999; Poole et al. 2001) and adenine (Hattman et al. 1978; Vanyushin 2005), catalyzed by DNA methyltransferase (MTase) enzymes. MTases utilize Sadenosyl-L-methionine (AdoMet) methyl donors to transfer methyl groups to an array of nucleophiles (Wu and Santi 1985), such as nitrogen, oxygen, sulfur, and activated carbon atoms in DNA (Bujnicki and Radlinska 1999; Cheng and Roberts 2001). Eubacteria, archaea, protists, fungi, plants, invertebrates, and vertebrates contain DNA methylation. However, methylation is not universal to the eukaryotic kingdom because organisms such as, Saccharomyces cerevisiae, Schizosaccharomyces pombe, and Caenorhabditis elegans lack detectable methylation signatures in their genomes (Colot and Rossignol 1999).

There are three main forms of DNA methylation: 5-methylcytosine $(5 \mathrm{mC}), \mathrm{N} 4-$ methylcytosine (N4mC) and, N6-methyladenine (N6mA) (Bujnicki and Radlinska 1999) (Figure 1). $5 \mathrm{mC}$ is universal to all three domains of life, with few exceptions. By contrast, $\mathrm{N} 6 \mathrm{~mA}$ is found in eubacteria, the nuclear genome of ciliated protists Tetrahymena pyriformis and Paramecium aurelia, dinoflagellate Peridinium triquetrum, green algae, fungi, and organelle genomes of plants (Hattman et al. 1978; Vanyushin 2005). N4mC is only found in thermophilic and mesophilic eubacteria, archaea, and in RNA of the small ribosomal subunits of insect and mammalian mitochondria (Woese et al. 1975; Dubin and Hsuchen 1983; Ehrlich et al. 1987; Noyer-Weidner and Trautner 1993; Bujnicki and Radlinska 1999; Sartori et al. 2002). Some flagellate protists such as kinetoplastids and dinoflagellates produce two alternative forms of DNA methylation, $\beta$-D-glucosol-hydroxymethyluracil ( $\beta$-Gluc-HOMeUra) and 5hydroxymethyluracil respectively (Rae 1973; van Leeuwen et al. 1998) (Figure 2). 


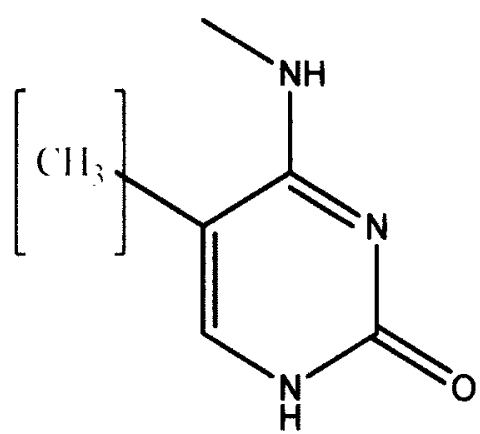

5-methyl cytosine

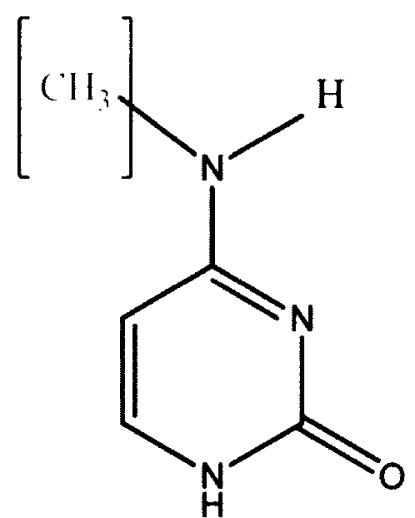

N4-methyl cytosine

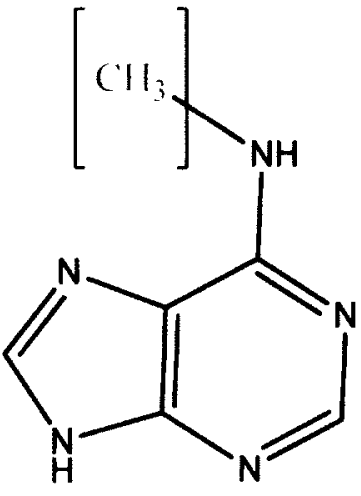

N6-methyl adenine

Figure 1. Three main types of covalently methylated nitrogenous base products.

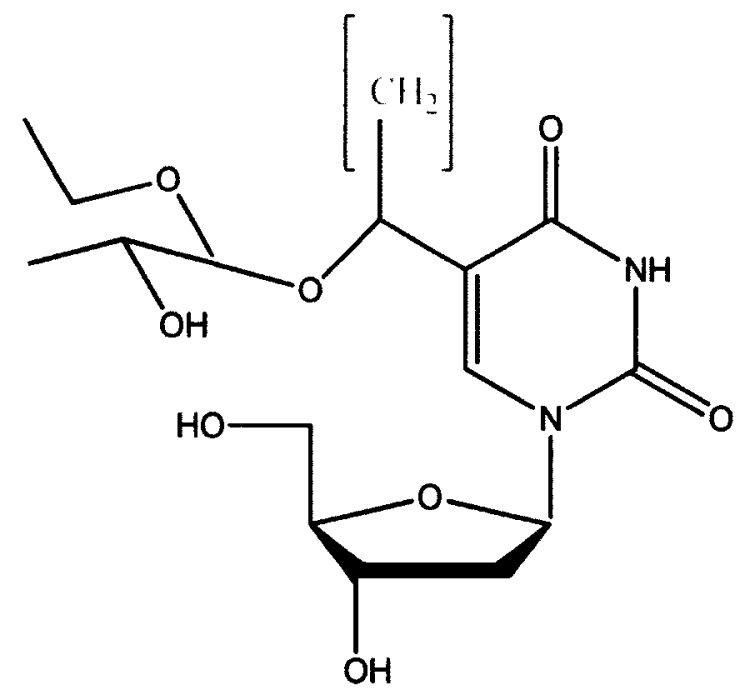

B-D-glucosyl-hydroxymethyluracil<smiles>CCC(O)c1c[nH]c(=O)[nH]c1=O</smiles>

5-methylhydroxyluracil

Figure 2. Alternative forms of DNA methylation. Hexameric repeat arrays of chromosome telomeres and adjacent repetitive sub-telomeric DNA of kinetoplastids contains $\beta$-D-glucosylhydroxymethyluracil, also referred to as $\mathrm{J}$. A majority of dinoflagellate genomes contain 5hydroxyuracil, and, on average, nearly $40 \%$ of thymine is replaced by 5 -hydroxyuracil. Thymine is merely methylated uracil.

The presumptive functions and sequence specificity of DNA methylation varies among eubacteria, archaea, and eukarya. Eukaryotic DNA methylation regulates gene expression, genomic immunity, genomic imprinting, genome-wide epigenetic resets, heterochromatin 
formation, and determination of primary sex characteristics (Hall 1990; Barlow 1993; Haig 2002; Farthing et al. 2008; Gorelick. and Carpinone 2009; Kaneko-Ishino and Ishino 2010;

Gorelick et al. 2011). In contrast, eubacteria and archaea use methylation as part of the restriction modification systems (rm) I, II, and III, to protect themselves from exogenous DNA insertions (Razin and Razin 1980; Zillig et al. 1988; Noyer-Weidner and Trautner 1993; Kobayashi et al. 1999; Grogan 2003).

Restriction modification ( $\mathrm{rm}$ ) systems of eubacteria and archaea can be divided into different types according to subunit composition and cofactor requirements (Wilson 1991; Wilson and Murray 1991). Type I rm system consists of three types of subunits, ' $r$ ' for restriction, ' $\mathrm{m}$ ' for modification, and ' $\mathrm{s}$ ' for specificity and recognize bipartite recognition sequences. Methyl modification takes places within the recognition sequence, while cleavage takes place either upstream or down-stream and requires AdoMet, as well as large amounts of ATP hydrolysis (Bickle and Krüger 1993). Type III rm system consists of two subunits: ' $r$ ' and ' $m$ '. Restriction enzymes of the rm III system require both ' $r$ ' and ' $m$ ' subgroups, as well as the presence of ATP while the methyltransferase functions in the presence of AdoMet. The modification takes place within the recognition site, however, the cleavage happens approximately $25 \mathrm{bp}$ downstream of the recognition site (Bickle and Krüger 1993).

Eubacterial restriction modification system II functions with two independent enzymatic units: homodimeric restriction enzymes (ENases) and monomeric DNA methyltransferases (MTases). The ENases have endonuclease activity that target the invading transposable elements and are not dependent on AdoMet or ATP to function (Pingoud and Jeltsch 1997; Nagornykh et al. 2008). Methyltransferases have DNA methylation capability and only require AdoMet as a cofactor to function (Razin and Riggs 1980; Razin et al. 1984; Nagornykh et al. 2008). 
Endonucleases are highly sequence-specific and species-specific enzymes that target and cleave exogenous and endogenous nucleotides (Wilson 1991). For example, EcoRI restriction endonuclease cleaves DNA only at recognition site G/AATTC and produce 5'sticky ends in Escherichia coli, whereas BamHI only cleaves DNA at recognition sequence site G/GATCC in Bacillus amyloliquefaciens (Dale and Park 2010). EcoRI restriction endonuclease cannot function in the absence of palindromic recognition sequences nor in species other than Escherichia coli, specificity also found in BamHI and hundreds of other restriction enzymes.

I exclusively analyzed the type II $\mathrm{rm}$ system because it can be studied in the absence of endonuclease (restriction) activity, unlike with type I and III rm system, in which a single enzymatic unit performs the dual functions of methylation and restriction cleavage. Type II restriction enzymes typically recognize palindromic recognition sites that are 4-8bp in length, and the modification and cleavage occur within the recognition sites. In addition, type II restriction modification is the most prominent and frequently occurring genomic line of defense in a majority of eubacterial species and has the capability to produce N6-methyladenine, N4methylcytosine and 5-methylcytosine. The role, ubiquity, diversity, and independent evolution of rm system II suggests that it plays an important role in the population structure and (co)evolution of bacteria with invading exogenous DNA elements (Levin 1993).

Exogenous DNA elements, such as viruses, repetitive elements, transposons, and retrotransposons, are capable of rapid mobilization via transposition (McClintock 1950; Kimura 1968; Bestor 1990; Levin 1993; Bheemanaik et al. 2006; Suzuki et al. 2007; Harony and Ankri 2008; Kaneko-Ishino and Ishino 2010). Transposons are present in almost all eubacteria, archaeabacteria, and eukarya, and occupy a significant portion of the genome. For example, about half of the human genome is derived from transposable elements (Boyes and Bird, 1991), 
with more than a dozen hominoid functional genes originating from ancestral transposons (Lander et al. 2001; Allis et al. 2007). Transposons have a high degree of genetic and functional diversity and remarkable ability to adapt and thrive within host lineages. Some eubacterial species require exogenous DNA for the survival and spread while in other eubacterial species exogenous DNA enhance the ability of eubacterial populations to colonize and adapt to changing environments (McClintock 1950). Previous studies have shown that exogenous DNA provides (1) aid in the production of allelopathic agents such as bacteriocins (Tani and Nasu 2010), (2) protection against pathogens (Levin 1993), oxidation and fermentation of toxic carbon compounds (Liu 2006), and (3) resistance to the adverse effects of ultraviolet light, heavy metals (He and Hader 2002), and antibiotics (Courvalin 1994; Walker 1996; Tani and Nasu 2010).

Some transposable elements lack a strong target site preference, and their distribution appears more or less random. However, transposition is rarely fully random and majority of transposons are highly selective for the sites where they insert. A primary example for targeted transposition is the bacterial $\operatorname{Tn} 7$ transposon. $\operatorname{Tn} 7$ is highly specialized to insert into a single sequence motif in the E. coli genome (Lichtenstein and Brenner 1982). Kirchner et al. (1995) and Devine and Boeke (1996) showed that Ty LTR retrotransposons of the yeast S. cerevisiae genome exhibit strong integration bias into Tyl and Ty3 elements that are upstream of RNA polymerase III transcribed genes. The single-celled eukaryote, Dictyostelium discoideum has a highly compact genome, and transposons in $D$. discoideum employ two strategies for sitedirected insertion. One strategy is to integrate into previously inserted transposon clusters (Loomis et al. 1995). The other strategy is targeted insertion into non-protein coding regions of the genome (Craigie et al. 1987; Winckler et al. 2005). However, the question of whether 
transposons preferentially insert in methylated regions of the host genome has yet to be answered.

The genomic autoimmunity hypothesis is the primary hypothesis that addresses the role of DNA methyltransferases in the restriction modification system II of eubacteria and archaeabacteria. The genomic autoimmunity hypothesis postulates that the "cognate" methyltransferases have evolved to hypermethylate endonuclease recognition sites in order to protect the host genome against its own restriction cleavage, a preventative method against genomic autoimmunity (Razin et al. 1984; Nagornykh et al. 2008; Dale and Park 2010). In other words, eubacteria and archaea use DNA methyltransferase enzymes to hypermethylate host loci to prevent endonuclease restriction cleavage of host's genomic material. However the genomic autoimmunity hypothesis cannot explain the occurrence of the "rare cutter" restriction enzymes whose lengthy recognition sequences (approximately eight to ten base pairs) are unlikely to be present in many eubacterial viruses and/or transposable elements (Naito et al. 1995) and often lead to the restriction of host DNA.

Wilson and Murray (1991) showed that the genes encoding the restriction modification unit of EcoRI are capable of leaving the eubacterial genome via plasmids and thus participate frequently in horizontal gene transfer. In a majority of cases, the methyltransferases and endonuclease restriction enzymes do not leave the bacterial host cell in unison, but rather participate independently in horizontal gene transfer (Jeltsch and Pingoud 1996). Therefore, at times the host genome is left with endonuclease restriction enzymes without the corresponding methyltransferases, which results in the death of the bacterial host cell. Thus, Dawkins (1989) and Naito et al. (1995) describe the behavior of the restriction modification system II as parasitic, symbiont, and "selfish," mobile genetic elements. 
Furthermore, Type II DNA methyltransferases do not distinguish between endogenous and exogenous DNA (Lauster et al. 1989). Rather, DNMTases search along a given DNA strand and covalently modify cytosine and adenine nitrogenous bases. The DNA target-recognition domains (TRD's) of the amino acid chain of type II MTases are responsible for identifying the methylase recognition sites (Lauster et al. 1989; Kumar 2004). However, Lauster et al. (1989) postulated that eubacterial type II MTases do not have an enzymatic domain that regulates the identification of self to non-self. According to Kruger and Reuter (1999) and Kumar (2004) the target recognition domain (TRD) is not conserved between different groups of eubacterial MTases, and is completely devoid of self-recognition motifs. A significant characteristic of eubacterial DNA methylation is that eubacterial MTases will methylate all available target sites without discrimination as long as the sites are found within the methylase recognition sequences (Kumar 2004).

Is there a fundamental difference between exogenous and endogenous DNA in eubacteria and archaeabacteria? If there is no, how can the host genome protect itself against extracellular invaders? Even though, type II methyltransferases cannot distinguish between exogenous and endogenous DNA, transposons and retrotransposons have unique structural characteristics that differ from the host's genomic material. All DNA transposons belonging to eubacteria and archaeabacteria contain two sets of flanking repeat sequences referred to as IS (insertion sequence) elements and/or IS-like elements. The IS elements are either direct or inverted repeats ranging from 20-40bp in length (Starlinger 1980; Calos and Miller 1980). All DNA transposons also carry the transposase gene that is essential for transposition. Transposase is a transposoncoded DNA binding protein that is essential for the formation of the transposome, a nucleoprotein synaptic complex. Transposomes contain the DNA of the transposable element, 
the transposon-encoded transposase enzyme, targeted host DNA, and host-encoded proteins factors (Surret et al. 1987; Agrawal et al. 1998; Hiom et al. 1998; Izsvaik et al. 2002; Kapitonov and Jurka 2005; Walisko et al. 2006).

Calos and Miller (1980) postulated that the insertion sequences and/or transposase gene can be used as molecular markers to locate transposon-derived genes in eubacteria and eukarya because the insertion sequences and/or the transposase gene remain as part of the host genome post-transposition. Rice and Marshall (1992) discovered the presence of conserved 121bp-long inverted repeats belonging to $\mathrm{Tn} 552$ and $\mathrm{Tn} 4002$ transposons in the transposon-derived, betalactamase gene in Enterococcus faecalis strains CH19 and CX19. Tamura et al. (2000) used the conserved, inverted terminal repeats of piggyBac transposon in the germline of the silkworm, Bombyx mori to confirm if piggyBac transposition is transgenerational. Furthermore, Youngson et al. (2005) showed that the sushi-ichi transposase gene is highly conserved and remains intact in nine Ty3/gypsy retrotransposon-derived mammalian-genes. Kapitonov and Jurka (2004) identified a widely expressed HARBI1 gene encoding a 350 amino acid protein that is entirely derived from Harbinger transposase belonging to the Harbinger superfamily of DNA transposons. The HARBIl gene is believed to have transposed 450-500 million years ago and is conserved in humans, rats, mice, cows, pigs, chickens, frogs, and bony fish. Therefore, even though host-encoded, type II methyltransferases cannot distinguish between exogenous and endogenous DNA, transposons and retrotransposons have unique structural characteristics such as flanking insertion sequences and transposase genes. Insertion sequences and/or transposase genes are conserved in transposon-derived genes in eubacteria and eukarya and thus can be used to set apart transposon-derived elements from host genomic material. 
Based on the notion that transposable elements are structurally unique pre and post transposition, I present a modified version of the genomic autoimmunity hypothesis termed the "transposon-mediated immunity hypothesis", which emphasizes the possible role of transposable elements in regulating the function of type II DNA methyltransferases. I hypothesize that gene regulation via DNA methylation originated in ancestral eubacteria as a transposonmediated countermeasure to endonuclease cleavage. Transposon-coded proteins influenced eubacterial DNMTases into hypermethylating eubacterial restriction endonuclease sites. This decreases restriction enzyme's accessibility to palindromic sequences and may prevent $\mathrm{rm}$ system II from removing transposable elements from the genome (Figure 3). Therefore, I predict that "cognate" methyltransferase sites (methylation conferred by species-specific MTases) present in a majority of microbial genomes are similar in nucleotide identity and frequency of occurrence to restriction endonuclease sites. 
1) Restriction endonuclease site of Ecor
5' -AGACGGGATTCTAGGACGAATTCGPTACAAAGCGCGC-3'
3'-TCTGCCCTAAGATCCTGGCTTAAGCAACTGTTTCGCGCG-5'

2)

Dcm methylase site 5' -AGACGGGATTC AGGACCFAATCGTTGACAAAGCGCGC-3' $3^{\prime}$-TCTGCCCTAAGATCCTGGCTTAAGCAACTGTTTCGCGCG-5'

3)

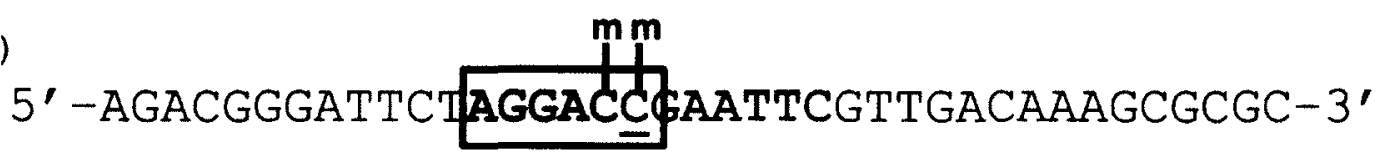

3' -TCTGCCCTAAGATCCTGGCTTAAGCAACTGTTTCGCGCG-5'

4)

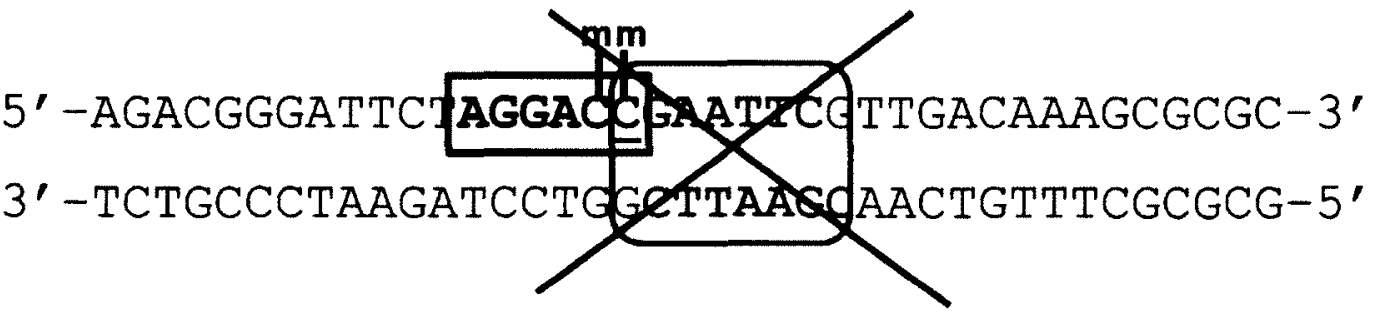

Figure 3. Methylation of palindromic sites prevents systematic cleavage of transposons by endonuclease restriction enzyme, EcoRI. 1) EcoRI is part of the restriction endonuclease system and uses palindromic sequence GAATTC to attach and initiate exogenous DNA cleavage. 2) GGACC is the target sequence for $D c m$ methylase enzyme. Due to specificity of Dcm methylase, only nucleotide sequences that are identical to its methylation pattern will undergo covalent modification. 3) Post-methylation of CCAGG sequence by $\mathrm{Dcm}$ methylase. Black lines represent the added methyl groups to the cytosine nitrogenous bases and the green colored cytosine represent the overlapping region between methylase and restriction sites. 4) $E c o R I$ restriction enzyme can no longer gain access to the restriction site to initiate cleavage due to molecular hindrance created by the added methyl groups.

\section{Materials and methods:}

\section{Sequence comparison}

I extracted 666 palindromic restriction sequences of 344 endonuclease enzymes and 466 corresponding methylase sequences of 212 "cognate" type II methyltransferases for 261 microbial species belonging to archaea and eubacteria. In order to avoid sampling bias, I did not 
pick the 261 species, but rather chose the 344 most prominent endonuclease restriction enzymes that are exclusive to the restriction modification system II. These 344 enzymes are not present in species that use type I or type III restriction modification systems. I used the online restriction enzyme database REBASE at http://rebase.neb.com/rebase/rebase.html, NCBI GenBank at http://www.ncbi.nlm.nih.gov/genbank/, volume 5 of Gene Amplification and Analysis (Roberts 1987), and Blakesley et al. (1981) to collect the sequence information. Then I used ClustalX2 (Larkin et al.2007) to align each endonuclease sequence with the corresponding methylase sequence to calculate the percent nucleotide identity.

Next, I quantified the total number of methylated restriction sites for each of the 68 species (66 eubacterial and 2 archaeabacterial) in 27 families. The sample size reduced from 261 to 68 species due to lack of sequence data available on GenBank, i.e. a majority of the eubacterial species that I used in the analysis were not sequenced at these loci.

I extracted fully and partially sequenced 16 S ribosomal RNA sequences in FASTA format and obtained the corresponding accession numbers from NCBI GenBank. I used the $16 \mathrm{~S}$ rRNA gene because it is one of the few gene loci that are conserved amongst all eubacterial species. I attempted to use $12 \mathrm{~S}$ rRNA and RNA polymerase $\beta$ as secondary and tertiary molecular markers to validate the results. However, the amount of nucleotide data available from GenBank for 12S rRNA and RNA polymerase $\beta$ was insufficient.

I used two types of species-specific reference probes: probes exclusively targeting the methylase sequences and probes exclusively targeting the endonuclease restriction sequences. I quantified the hybridization between the probes and the target sequences, as well as the 
overlapping regions between methylase and endonuclease sites using seqinr (Charif and Lobry 2007) and ape (Paradis et al. 2004) packages in R.

\section{Phylogenetic construction}

I used the $16 \mathrm{~S}$ rRNA sequences to create a phylogeny for the 38 eubacterial and two archaeabacterial species in 23 families that showed positive hybridization between the probes and the target sequences. I used MEGA version 5.05 (Tamura et al. 2011) for the phylogenetic and molecular evolutionary analyses and used ClustalX2 for the pairwise and multiple sequence alignments. I used the alignment scores and three published eubacterial and archaeabacterial supertrees (Ludwig and Schleifer 1994; Daubin et al. 2001; Case et al. 2007) to construct a consensus tree based on maximum likelihood in MEGA 5.05. I calculated bootstrap confidence intervals for each node of the phylogeny with 500 bootstrap replicates. I constructed a phylogeny based on maximum likelihood, as opposed to maximum parsimony, because maximum likelihood is computationally more accurate than maximum parsimony.

\section{Phylogenetic signal}

I computed Pagel's lambda $(\lambda)$ correlation using Phytools and Geiger packages in $\mathrm{R}$ to test for phylogenetic dependence between the total number of endonuclease and methylase sites in 68 microbial species.

Pagel's lambda $(\lambda)$ is the most common way to estimate phylogenetic signal. The test assumes a constant-variance, random effects model of evolution and is based on maximum likelihood (Pagel 1999). Pagel's $\lambda$ varies between 0 (phylogenetic independence) and 1 (phylogenetic dependence). I calculated Pagel's lambda for the total number of endonuclease and methylase sites corresponding to the original, 16S rRNA tree of the 40 taxa (Figure 4, Appendix 
II). Then I transformed the original $16 \mathrm{~S}$ rRNA tree with 40 taxa into a null tree with uniform branch lengths, portraying zero phylogenetic relatedness between the 40 species, and again calculated Pagel's $\lambda$. If the lambda value for the 16S rRNA tree is less or equal to the lambda value for the null tree, then I considered the data set to be independent and lacking phylogenetic covariance. Annotated R codes for all the above analyses are in Appendix I.

\section{Results}

ClustalX2 alignment of the 666 palindromic endonuclease restriction sequences with the 466 species-specific, methylase sequences produced $100 \%$ nucleotide identity.

The total number of methylated restriction sites in the 16S rRNA gene locus of 40 microbial taxa yielded $100 \%$ overlap between endonuclease restriction sites and the "cognate" methylase sites $\left(\mathrm{R}^{2}=1.00\right)($ Table 1$)$. The number of endonuclease restriction sequences for each species was identical to the number of methylase sequences for that species. In other words, every species contained an equal number of restriction sites and methylase sites at the $16 \mathrm{~S}$ rRNA locus.

However, I saw something unexpected in 28 out of the 68 microbial species, in that they contained neither endonuclease restriction nor methylase sites (Table 2). 
Table 1. Total number of type II endonuclease restriction sites, number of methylase sites, and number of overlapping sites in $16 \mathrm{~S}$ rRNA genomes of 40 microbial species in 23 families.

\begin{tabular}{|c|c|c|c|}
\hline Microorganisms & $\begin{array}{c}\text { Number of } \\
\text { endonuclease } \\
\text { restriction sites }\end{array}$ & $\begin{array}{c}\text { Number of } \\
\text { methylase } \\
\text { sites* }\end{array}$ & $\begin{array}{c}\begin{array}{c}\text { Number } \\
\text { of } \\
\text { overlaps }\end{array} \\
\end{array}$ \\
\hline Acetobacter aceti & 1 & 1 & 1 \\
\hline Acetobacter pasteurianus & 1 & 1 & 1 \\
\hline Anabaena flos-aquae & 2 & 2 & 2 \\
\hline Anabaena variabilis & 4 & 4 & 4 \\
\hline Arthrobacter protophormiae & 1 & 1 & 1 \\
\hline Bacillus brevis & 3 & 3 & 3 \\
\hline Bacillus firmus & 2 & 2 & 2 \\
\hline Bacillus smithii & 1 & 1 & 1 \\
\hline Bacillus subtilis & 12 & 12 & 12 \\
\hline Citrobacter freundii & 3 & 3 & 3 \\
\hline Clostridium formicoaceticum & 2 & 2 & 2 \\
\hline Deinococcus radiophilus & 2 & 2 & 2 \\
\hline Desulfovibrio desulfuricans, Norway strain & 3 & 3 & 3 \\
\hline Enterobacter cloacae & 1 & 1 & 1 \\
\hline Flavobacterium aquatile & 1 & 1 & 1 \\
\hline Flavobacterium okeanokoites & 2 & 2 & 2 \\
\hline Fusobacterium nucleatum & 15 & 15 & 15 \\
\hline Gluconobacter oxydans & 1 & 1 & 1 \\
\hline Haemophilus aegyptius & 7 & 7 & 7 \\
\hline Haemophilus aphrophilus & 6 & 6 & 6 \\
\hline Haemophilus haemoglobinophilus & 6 & 6 & 6 \\
\hline Haemophilus haemolyticus & 11 & 11 & 11 \\
\hline Haemophilus parahaemolyticus & 4 & 4 & 4 \\
\hline Haemophilus parainfluenzae & 7 & 7 & 7 \\
\hline Methanothermobacter wolfei & 6 & 6 & 6 \\
\hline Methylophilus methylotrophus & 6 & 6 & 6 \\
\hline Micrococcus species CCGE3063 & 5 & 5 & 5 \\
\hline Moraxella bovis & 9 & 9 & 9 \\
\hline Moraxella nonliquefaciens & 10 & 10 & 10 \\
\hline Moraxella species 0408225 & 4 & 4 & 4 \\
\hline Neisseria lactamica & 2 & 2 & 2 \\
\hline Providencia alcalifaciens & 8 & 8 & 8 \\
\hline Pseudomonas fluorescens & 1 & 1 & 1 \\
\hline Rhodopseudomonas sphaeroides & 3 & 3 & 3 \\
\hline
\end{tabular}


Streptococcus cremoris

Streptomyces phaeochromogenes

Thermoplasma acidophilum

Thermus aquaticus

Thermus filiformis

Xanthomonas campestris

* The number of restriction and methylase sites for type II endonuclease and methylase enzymes represents the total for a species. Refer to the supplementary material (S2) for a complete list of results categorized by each enzyme.

Table 2. 28 microbial species with zero endonuclease and methylase sites in the 16S rRNA gene locus

\begin{tabular}{ll}
\hline Acinetobacter calcoaceticus & Neisseria mucosa \\
Agrobacterium gelatinovorum & Plesiomonas shigelloides 319-73 \\
Agrobacterium tumefaciens C58 & Proteus vulgaris \\
Arthrobacter ON14 & Providencia stuartii 164 \\
Bacillus amyloliquefaciens & Pseudomonas aeruginosa \\
Bacillus caldolyticus & Saccharopolyspora hirsute ATCC 2787 \\
Bacillus coagulans & Serratia marcescens \\
Bacteroides caccae ATCC43185T & Sphaerotilus natans \\
Caryophanon latum L & Staphylococcus warneri \\
Erwinia toletana & Streotomyces caespitosus \\
Haemophilus influenza & Streptomyces albus \\
Micrococcus luteus & Streptomyces fimbriatus \\
Mycoplasma fermentans & Streptomyces griseus \\
Neisseria denitrificans & Xanthomonas oryzae \\
\hline
\end{tabular}

The molecular phylogeny of the 40 microbial species in 23 families generated a consensus tree (Figure 4, Appendix II). My estimated phylogeny matches previously published, molecular phylogenies based supertrees (Ludwig and Schleifer 1994; Daubin et al. 2001; Case et al. 2007). 
Phylogenetic signal analysis using Pagel's lambda $(\lambda)$ correlation produced a lambda value of $1.0 \times 10^{-5}$ for the original, $16 \mathrm{~S}$ rRNA tree of the 40 microbial species. The transformed, null, tree with uniform branch lengths produced a lambda value of 0.5 .

\section{Discussion}

I tested whether hypermethylation of protein-coding genes in eubacteria and archaea might be a host-driven mechanism against exogenous DNA invasions. Alternatively, do exogenous DNA mediate eubacterial DNA methyltransferase enzymes into hypermethylating the eubacterial palindromic recognition sites to avoid restriction cleavage? Genomic autoimmunity hypothesis, postulated that the host genomic machinery regulates the enzymatic dynamics of endonuclease and methylase enzymes of rm system II to minimize the spread of exogenous DNA elements. However, I hypothesized that gene regulation via DNA methylation may have originated in ancestral eubacteria as a transposon-mediated countermeasure to endonuclease cleavage. I predicted that transposon-coded proteins may have influenced eubacterial DNMTases into hypermethylating eubacterial restriction endonuclease sites. This decreases endonuclease enzyme's accessibility to palindromic sequences and may render rm system II ineffective at removing transposable elements from the genome. The fundamental message of the transposonmediated immunity hypothesis is that endonuclease restriction enzymes and methyltransferases of rm system II function as independent enzymatic units and that type II DNA methyltransferases may not necessarily improve the effectiveness of rm system II against transposon invasions.

I showed that there is a significant correlation between the palindromic restriction endonuclease sequences and the "cognate" methylase sequences in eubacteria and archaea. This 
corroborates the findings of Noyer-Weidner and Trautner (1993) and Geier and Modrich (1979) by showing that the addition of methyl moieties to restriction recognition sequences seems to prevent endonucleases from binding to and forming a stable enzyme-substrate complex with palindromic recognition sites.

The sequence alignment of the 666 palindromic, endonuclease restriction sequences with the 466 , "cognate" methylase sequences produced $100 \%$ nucleotide identity. However, I did not calculate the percent identity of 200 endonuclease restriction sequences due to the lack of published sequence data available for the corresponding methylase sequences. Nevertheless, I predict that the remaining 200 restriction sequences will yield similar results.

I used $16 \mathrm{~S}$ rRNA to build the phylogeny for the 66 eubacterial and 2 archaeal species because 16S rRNA is ubiquitous and one of the few housekeeping genes, along with RNA polymerase $\beta$ subunit gene ( $r p o B)$, that is highly conserved among eubacteria and archaea. Since 1990 , the use of $16 \mathrm{~S}$ rRNA as a genomic marker has revolutionized microbiology in understanding phylogenetic diversity (Amann et al. 1990; García-Martínez et al. 1999; Case et al. 2007).

The reason why the endonuclease sequence probes and the methylase sequence probes failed to hybridize with the $16 \mathrm{~S}$ rRNA sequences for 28 out of 68 microbial species (Table 2) is probably because, according to Case et al. (2007), multiple copies of 16S rRNA gene are often present in a given bacterium and intragenomic copies can differ in sequence identity. These heterogeneity hot spots were found in a majority of gene fragments that are commonly used in molecular phylogenetic analysis and the hot spots can influence hybridization of primers and probes, 16S rRNA gene tree topology, and phylogenetic resolution at the species level (Case et 
al. 2007). Lack of hybridization between endonuclease and methylase probes and the target sequences in the 28 microbial taxa does not mean that these species completely lack endonuclease and methylase sites. I did not probe the complete genomes of the 68 microbial species to quantify the total number of endonuclease and methylase sites. For each species, I probed the 16S rRNA locus, which represents a small portion of each microbial genome. Lack of hybridization simply means that the $16 \mathrm{~S}$ rRNA genomic regions in which I probed for hybridization, in fact, lack the targeted endonuclease and methylase sites. In addition, the $16 \mathrm{~S}$ rRNA loci that I extracted from NCBI GenBank for the 28 eubacterial species with zero hybridization were all partial sequences that ranged from $241 \mathrm{bps}$ to $721 \mathrm{bps}$. This is approximately one quarter the size of the remaining $16 \mathrm{~S}$ rRNA loci that I used in the analysis, which are well over $1561 \mathrm{bps}$.

Phylogenetic comparative methods are commonly used in interspecific comparative studies (Martins and Hansen 1997; Price 1997; Freckleton et al. 2002; Blomberg et al. 2003) because species that are closely related tend to share similar trait values compared to species that are distantly related. Statistical non-independence that arises due to phylogenetic distance can be resolved using phylogenetic comparative methods, such as independent contrasts and phylogenetic generalized least squares regression (Blomberg et al. 2003; Felsenstein 1985; Grafen 1989). However, it is not necessary to control for phylogenetic bias in all comparative studies (Bjorklund 1994; Fitter 1995; Losos 1999). I did not use the phylogenetic comparative method in this study because Pagel's lambda $(\lambda)$ indicated that my data on total number of endonuclease and methylase sites lacked a phylogenetic signal.

Currently the most widely accepted hypothesis regarding the origin of eubacterial and archaeabacterial rm system II is the genomic autoimmunity hypothesis that describes $\mathrm{rm}$ II as the 
main line of genomic defense against exogenous DNA. The genomic autoimmunity hypothesis emphasizes that DNA methyltransferase enzymes protect the host genome from exogenous DNA insertions and the host genomic machinery is solely responsible for regulating the function and maintenance of restriction modification and methyltransferase enzymes.

In this thesis, I presented a modified version of the genomic autoimmunity hypothesis, namely the transposon-mediated immunity hypothesis, which postulates that the presence of DNA methylation as part of the restriction modification system II of eubacteria and archaea is not a host-driven mechanism against transposition, but may be a transposon-mediated countermeasure to gain access to the host genome via bypassing endonuclease cleavage. I found that palindromic endonuclease restriction sequences and "cognate" methylase sequences share $100 \%$ nucleotide identity in 210 eubacterial and 2 archaeabacterial species. Furthermore, the total number of restriction and methyltransferase sequences in the $16 \mathrm{~S}$ rRNA of 40 microbial species showed a perfect correlation $\left(\mathrm{R}^{2}=1.00\right)$. This result is consistent with the transposonmediated immunity hypothesis in that hypermethylation of endonuclease restriction sites by "cognate" DNMTases seem to render restriction modification system II ineffective at removing transposable elements from the genomes of eubacteria and archaeabacteria. 


\section{Bibliography}

Agrawal, A., Q.M. Eastman, and D.G. Schatz, 1998. Transposition mediated by RAG1 and RAG2 and its implications for the evolution of the immune system. Nature 394: 744-751.

Allis, D. C., T. Jenuwein, D. Reinberg, and M. Caparros, 2007. Epigenetics. Cold Spring Harbor Laboratory Press, Cold Spring Harbor.

Amann, R.I., B.J. Binder, R.J. Olson, S.W. Chisholm, R. Devereux, and D.A. Stahl, 1990. Combination of $16 \mathrm{~S}$ rRNA-targeted oligonucleotide probes with flow cytometry for analyzing mixed microbial populations. Applied and Environmental Microbiology 56: Applied and Environmental Microbiology 56: 1919-1925.

Barlow, D. P., 1993. Methylation and imprinting: from host defense to gene regulation? Science 260: $309-310$.

Bestor, T. H., 1990. DNA methylation: evolution of a bacterial immune function into a regulator of gene expression and genome structure in higher eukaryotes. Philosophical Transactions of the Royal Society of London. Series B, Biological Sciences 326: 179187.

Bheemanaik, S., Y. V. R. Reddy, and D. N. Rao, 2006. Structure, function and mechanism of exocyclic DNA methyltransferases. Biochemical Journal 399: 177-190.

Bickle, T. A., and D. H. Krüger, 1993. Biology of DNA restriction. Microbiological Reviews 57: 434-450.

Bjorklund, M., 1994. The independent contrasts method in comparative biology. Cladistics 10: 425-433.

Blakesley, R. W., 1981. Restriction endonucleases: specificities, diversities and computer analysis. Gene Amplification and Analysis 1: 1-43.

Blomberg, S. P., T. Garland, and A. R. Ives, 2003. Testing for phylogenetic signal in comparative data; behavioral traits are more labile. Evolution 57: 717-745.

Boyes, J., and A. Bird, 1991. DNA methylation inhibits transcription indirectly via a methylCpG binding protein. Cell 64: 1123-1134.

Bujnicki, J. M., and M. Radlinska, 1999. Molecular evolution of DNA-(cytosine-N4) methyltransferases: evidence for their polyphyletic origin. Nucleic Acids Research 27: 4501-4509.

Calos, M.P., J.H. Miller, 1980. Transposable elements. Cell 3: 579-595. 
Case, R. J., Y. Boucher, I. Dahllöf, C. Holmström, W. F. Doolittle et al., 2007. Use of 16S rRNA and rpoB genes as molecular markers for microbial ecology studies. Applied and Environmental Microbiology 73: 278-288.

Charif, D., and J. R. Lobry, 2007. A contributed package to the $\{R\}$ project for statistical computing devoted to biological sequences retrieval and analysis in Structural Approaches to Sequence Evolution: Molecules, Networks, Populations, edited by U. Bastolla, M. Porto, H.E. Roman, and M. Vendruscolo. Springer, New York, pp. 207-232.

Cheng, X., and R. J. Roberts, 2001. AdoMet-dependent methylation, DNA methyltransferases and base flipping. Nucleic Acids Research 29: 3784-3795.

Colot, V., and J. L. Rossignol, 1999. Eukaryotic DNA methylation as an evolutionary device. BioEssays 21: 402-411.

Courvalin, P., 1994. Transfer of antibiotic resistance genes between gram-positive and gramnegative bacteria. Antimicrobial Agents and Chemotherapy 38: 1447-1451.

Craigie, R., and K. Mizuuchi, 1987. Transposition of Mu DNA: joining of Mu to target DNA can be uncoupled from cleavage at the ends of Mu. Cell 51: 493-501.

Dale, J. W., and S. F. Park, 2010. Molecular Genetics of Bacteria. Wiley-Blackwell, West Sussex.

Daubin, V., M. Gouy, and G. Perriere, 2001. Bacterial molecular phylogeny using supertree approach. Genome Informatics 12: 155-164.

Dawkins, R., 1989. The Selfish Gene. Oxford University Press, Oxford.

Devine, S.E., and J.D. Boeke, 1996. Integration of the yeast retrotransposon Ty1 is targeted to regions upstream of genes transcribed by RNA polymerase III. Genes \& Development 10: $620-633$.

Dubin, D. T., and C. C. Hsuchen, 1983. The 3'-terminal region of mosquito mitochondrial small ribosomal-subunit RNA-sequence and location of methylated residues. Plasmid 9: 307320.

Ehrlich, M., G. G. Wilson, K. C. Kuo, and C. W. Gehrke, 1987. N4-methylcytosine as a minor base in bacterial DNA. Journal of Bacteriology 169: 939-943.

Farthing, C. R., G. Ficz, R. K. Ng, C. F. Chan, S. Andrews et al., 2008. Global mapping of DNA methylation in mouse promoters reveals epigenetic reprogramming of pluripotency genes. PLoS Genetics 4: e1000116.

Felsenstein, J., 1985. Phylogenies and the comparative method. American Naturalist 125: 1-15. 
Fitter, A.H., 1995. Interpreting quantitative and qualitative characteristics in comparative analyses. Journal of Eology 83: 730.

Freckleton, R.P., P.H. Harvey, and M. Pagel, 2002. Phylogenetic analysis and comparative data: a test and review of evidence. American Naturalist 160: 712-726.

García-Martínez, J., S. G. Acinas, A. I. Antón., and F. Rodríguez-Valera, 1999. Use of the 16S$23 \mathrm{~S}$ ribosomal genes spacer region in studies of prokaryotic diversity. Journal of Microbiological Methods 36: 55-64.

Geier, G.E., and P. Modrich, 1979. Recognition sequences of the Dam methylase of Escherichia coli $\mathrm{K} 12$ and mode of cleavage of Dpn endonuclease. Journal of Biological Chemistry 254: 1408-1413.

Gorelick, R., M. Laubichler, and R. Massicotte, 2011. Asxuality and epigenetic variation, in Epigenetics: Linking Genotype and Phenotype in Development and Evolution., edited by B. Hallgrimsson and B.K. Hall. University of California Press, San Francisco, pp. 87102.

Gorelick., R., and J. Carpinone., 2009. Origin and maintenance of sex: the evolutionary joys of self sex. Biological Journal of the Linnean Society 98: 707-728.

Grafen, A., 1989. The phylogenetic regression. Philosophical Transactions of the Royal Society of London. Series B, Biological Sciences 326: 119-157.

Grogan, D. W., 2003. Cytosine methylation by the Sual restriction-modification system: Implications for genetic fidelity in a hyperthermophilic archaeon. Journal of Bacteriology 185: 4657-4661.

Hackett, C.S., A. M. Geurts, and P.B. Hackett, 2007. Predicting preferential DNA vector insertion sites: implications for functional genomics and gene therapy. Genome Biology 8: S1-S12.

Haig, D., 2002. Genomic Imprinting and Kinship. Rutgers University Press, New Brunswick.

Hall, J. G., 1990. Genomic imprinting: review and relevance to human diseases. American Journal of Human Genetics 46: 857-873.

Harony, H., and S. Ankri, 2008. What do unicellular organisms teach us about DNA methylation? Trends in Parasitology 24: 205-209.

Hattman, S., C. Kenny, L. Berger, and K. Pratt, 1978. Comparative study of DNA methylation in three unicellular eucaryotes. Journal of Bacteriology 135: 1156-1157.

He, Y.-Y., and D.-P. Hader, 2002. Reactive oxygen species and UV-B: effect on cyanobacteria. Photochemical \& Photobiological Sciences 1: 729-736. 
Hiom, K., M. Malek, and M. Gallert, 1998. DNA transposition by the RAG1 and RAG2 proteins: a possible source of oncogenic translocations. Cell 94: 463-470.

Izsvaik, Z., D. Khare, J. Behlke, U. Heinemann, R.H. Plasterk., and Z. Ivics, 2002. Involvement of a bifunctional, paired-like DNA-binding domain and a transpositional enhancer in Sleeping Beauty transposition. Journal of Biological Chemistry 277: 34581-34588.

Jeltsch, A., and A. Pingoud, 1996. Horizontal gene transfer contributes to the wide distribution and evolution of type II restriction modification systems. Journal of Molecular Evolution 42: 91-96.

Kaneko-Ishino, T., and F. Ishino, 2010. Retrotransposon silencing by DNA methylation contributed to the evolution of placentation and genomic imprinting in mammals. Development Growth \& Differentiation 52: 533-543.

Kapitonov, V.V., and J. Jurka, 2005. RAGl core and V(D)J recombination signal sequences were derived from Transib transposons. PLoS Biology 3: e181.

Kapitonov, V.V., and J. Jurka, 2004. Harbinger transposons and an ancient HARBIl gene derived from a transposase. DNA and Cell Biology 23: 311-324.

Kimura, M., 1968. Evolutionary rate at the molecular level. Nature 217: 624-626.

Kirchner, J., C.M. Connolly, and S.B. Sandmeyer, 1995. Requirement of RNA polymerase III transcription factors for in vitro position-specific integration of a retrovirus-like element. Science 267: 1488-1491.

Kobayashi, I., A. Nobusato, N. Kobayashi-Takahashi, and I. Uchiyama, 1999. Shaping the genome restriction modification systems as mobile genetic elements. Current Opinion in Genetics \& Development 9: 649-656.

Kruger, D.V., and M. Reuter, 1999. Host controlled modification and restriction, in Encyclopedia of Virology, edited by A. Granoff and R.G. Webster. Elsevier, Oxford, pp. 758-763.

Kumar, S., 2004. DNA methyltransferases, structural themes, in Encyclopedia of Biological Chemistry, edited by W.J. Lennarz and D.M. Lane. Elsevier, New York, pp. 652-659.

Lander, E. S., L. M. Linton, B. Birren, C. Nusbaum, M. C. Zody et al., 2001. Initial sequencing and analysis of the human genome. Nature 409: 860-921.

Larkin, M.A., G. Blackshields, N.P. Brown, R. Chenna, P.A. McGettigan, H. McWilliam, F. Valentin, I.M. Wallace, A. Wilm, R. Lopez, J.D. Thompson, T.J. Gibson, and D.G. Higgins, 2007. Clustal W and Clustal X version 2.0. Bioinformatics, 23: 2947-2948. 
Lauster, R., T. A. Trautner, and M. Noyer-Weidner, 1989. Cytosine specific type II DNA methyltransferases: a conserved enzyme core with variable target recognizing domains. Journal of Molecular Biology 206: 305-312.

Levin, B. R., 1993. The accessory genetic elements of bacteria: existence conditions and (co)evolution. Current Opinion in Genetics \& Development 3: 849-854.

Lichtenstein, C., and S. Brenner, 1982. Unique insertion site of Tn7 in the E. coli chromosome. Nature 297: 601-603.

Loomis, W. F., D. Welker, J. Hughes, D. Maghakian, and A. Kupsa, 1995. Integrated maps of the chromosomes in Dictyostelium discoideum. Genetics 141: 147-157.

Losos, J.B., 1999. Uncertainty in the reconstruction of ancestral character states and limitations on the use of phylogenetic comparative methods. Animal Behaviour 58: 1319-1324.

Ludwig, W., and K. H. Schleifer, 1994. Bacterial phylogeny based on 16S and 23S rRNA sequence analysis. FEMS Microbiology Reviews 15: 155-173.

Martins, E. P., and T. F. Hansen, 1997. Phylogenies and the comparative method: A general approach to incorporating phylogenetic information into the analysis of interspecific data. American Naturalist 149: 646-667.

McClintock, B., 1950. The origin and behavior of mutable loci in maize. Proceedings of the National Academy of Sciences USA 36: 344-355.

Naito, T., K. Kusano, and I. Kobayashi, 1995. Selfish behavior of restriction modification systems. Science 267: 897-899.

Nagornykh, M. O., E. S. Bogdanova, A. S. Protsenko, A. S. Solonin, M. V. Zakharova et al., 2008. Regulation of gene expression in a type II restriction modification system. Russian Journal of Genetics 44: 523-532.

Noyer-Weidner, M., and T. A. Trautner, 1993. Methylation of DNA in prokaryotes. Experientia Supplementum 64: 39-108.

Pagel, M., 1999. Inferring the historical patterns of biological evolution, Nature 401: 877-884.

Paradis, E., J. Claude, and K. Strimmer, 2004. APE: analyses of phylogenetics and evolution in R language. Bioinformatics 20: 289-290.

Pingoud, A., and A. Jeltsch, 1997. Recognition and cleavage of DNA by type-II restriction endonucleases. European Journal of Biochemistry 246: 1-22.

Poole, A., D. Penny, and B. M. Sjoberg, 2001. Confounded cytosine! Tinkering and the evolution of DNA. Nature Reviews Molecular Cell Biology 2: 147-151. 
Price, T., 1997. Correlated evolution and independent contrasts. Philosophical Transactions of the Royal Society of London. Series B, Biological Sciences 352: 519-529.

Rae, P. M. M., 1973. 5-Hydroxymethyluracil in the DNA of a dinoflagellate. Proceedings of the National Academy of Sciences USA 70: 1141-1145.

Razin, A., H. Cedar, and A. Riggs, 1984. DNA Methylation; Biochemistry and Biological Significance. Springer, Basel.

Razin, A., and S. Razin, 1980. Methylated bases in mycoplasmal DNA. Nucleic Acids Research 8: $1383-1390$.

Razin, A., and A. Riggs, 1980. DNA methylation and gene function. Science 210: 604-610.

Rice, L.B., and S.H. Marshall, 1992. Evidence of incorporation of the chromosomal betalactamase gene of Enterococcus faecalis $\mathrm{CH} 19$ into a transposon derived from staphylococci. Antimicrobial Agents and Chemotherapy 36: 1843-1846.

Roberts, R. J., 1987. Restriction and modification enzymes and their recognition sequences in Restriction Endonucleases and Methylases, edited by J. G. Chirikjian. Elsevier, Washington, D.C., pp. 2-34.

Sartori, A. A., S. Fitz-Gibbon, H. J. Yang, J. H. Miller, and J. Jiricny, 2002. A novel uracil-DNA glycosylase with broad substrate specificity and an unusual active site. EMBO Journal 21: 3182-3191.

Starlinger, P., 1980. IS elements and transposons. Plasmid 3: 241-259.

Surette, M.G., S.J. Buch, and G. Chaconas, 1987. Transpososomes: stable protein-DNA complexes involved in the in vitro transposition of bacteriophage Mu DNA. Cell 49: 253-262.

Suzuki, S., R. Ono, T. Narita, A. Pask, J, G. Shaw et al., 2007. Retrotransposon silencing by DNA methylation can drive mammalian genomic imprinting. PLoS Genetics 3: e55.

Tamura, K., D. Peterson, N. Peterson, G. Stecher, M. Nei, and S. Kumar, 2011. MEGA5: molecular evolutionary genetics analysis using maximum likelihood, evolutionary distance, and maximum parsimony methods. Molecular Biology and Evolution 10: 27312239.

Tani, K., and M. Nasu, 2010. Roles of extracellular DNA in bacterial ecosystem. Extracellular Nucleic Acids. 25: 25-37. 
Tamura, T., C. Thibert, C.Royer, T.Kanda, A, Eappen et al., 2000. Germline transformation of the silkworm Bombyx mori L. using a piggyBac transposon-derived vector. Nature Biotechnology 18: 81-84.

van Leeuwen, F., R. Kieft, M. Cross and P. Borst, 1998. Biosynthesis and function of the modified DNA base beta-D-glucosyl-hydroxymethyluracil in Trypanosoma brucei. Molecular and Cellular Biology 18: 5643-5651.

Vanyushin, F., 2005. Methylation of adenine residues in DNA of eukaryotes. Molecular Biology 39: 557-566.

Walker, C. B., 1996. The acquisition of antibiotic resistance in the periodontal microflora. Periodontology 2000 10: 79-88.

Walisko, O., Z. Izsvak, K. Szabo, C.D. Kaufman, S. Herold, and Z. Ivics, 2006. Sleeping Beauty transposase modulates cell-cycle progression through interaction with Miz-1. Proceedings of the National Academy of Sciences USA 103: 4062-4067.

Wilson, G. G., 1991. Organization of restriction-modification systems. Nucleic Acids Research 19: $2539-2566$.

Wilson, G. G., and N. E. Murray, 1991. Restriction and modification systems. Annual Review of Genetics 25: 585-627.

Woese, C. R., G. E. Fox, L. Zablen, T. Uchida, L. Bonen et al., 1975. Conservation of primary structure in 16S ribosomal RNA. Nature 254: 83-86.

Wolffe, A. P., and M. A. Matzke, 1999. Epigenetics: Regulation through repression. Science 286: 481-486.

Wu, J. C., and D. V. Santi, 1985. On the mechanism and inhibition of DNA cytosine methyltransferases. Progress in Clinical and Biological Research 198: 119-129.

Youngson, N.A., S. Kocialkowaski, N. Peel, and A.C. Ferguson-Smith, 2005. A small family of sushi-class retrotransposon-derived genes in mammals and their relationship to genomic imprinting. Journal of Molecular Evolution 61: 481-490.

Zillig, W., P. Palm, W. D. Reiter, F. Gropp, G. Puhler et al., 1988. Comparative evaluation of gene expression in archaebacteria European Journal of Biochemistry 173: 473-482. 


\section{Appendix I}

S1. Restriction sequences of 344 type II endonuclease enzymes and 466 methylase sequences of 212 type II methyltransferases, belonging to 261 microbial species.

\begin{tabular}{|c|c|c|c|c|}
\hline Microorganism & $\begin{array}{c}\text { Restriction } \\
\text { enzyme }\end{array}$ & Recognition sequence & $\begin{array}{c}\text { Methylase } \\
\text { enzyme }\end{array}$ & Methylase sequence \\
\hline Acetobacter aceti & AatII & GACGT/C & M.AatII & GACGTC $^{\mathbf{b}}$ \\
\hline $\begin{array}{l}\text { Acebacter pasteurianus } \\
\text { sub.pasteurianus }\end{array}$ & ApaI & GGGCC/C & M.Apai & $\mathrm{GGG}_{\mathrm{m} 5 \mathrm{CCC}}$ \\
\hline $\begin{array}{l}\text { Acetobacter pasteurianus } \\
\text { Acinetobacter }\end{array}$ & ApaLI & G/TGCAC & M.ApaLI & G/TGCAC ${ }^{d}$ \\
\hline calcoaceticus & AccI & $\mathrm{GT} /(\mathrm{A}, \mathrm{C})(\mathrm{G}, \mathrm{T}) \mathrm{AC}$ & M.AccI & GTAGAm6C \\
\hline $\begin{array}{l}\text { Acinetobacter } \\
\text { calcoaceticus M4 }\end{array}$ & AclI & $\mathrm{AA} / \mathrm{CGTT}$ & M.AclI & $\mathrm{AAm} 5 \mathrm{CGTT}$ \\
\hline $\begin{array}{l}\text { Agrobacterium } \\
\text { gelatinovorum }\end{array}$ & AgeI & $\mathrm{A} / \mathrm{CCGGT}$ & M.AgeI & $\mathrm{A} / \mathrm{CCGGT}^{\mathrm{d}}$ \\
\hline $\begin{array}{l}\text { Agrobacterium } \\
\text { tumefaciens C58 }\end{array}$ & $\begin{array}{l}\text { AtuCla } \\
\text { (BcII) }\end{array}$ & GANTC & M.AtucI & $\mathrm{G}^{\mathrm{m} 6}$ ANTC \\
\hline Anabaena flos-aquae & AflII & C/TTAAG & M.AflII & C/TTAAG ${ }^{b}$ \\
\hline Anabaena flos-aquae & AflIII & $\mathrm{A} / \mathrm{C}(\mathrm{G}, \mathrm{A})(\mathrm{C}, \mathrm{T}) \mathrm{GT}$ & M.AflIII & $\mathrm{A}^{\mathrm{m} 4} \mathrm{C}(\mathrm{G}, \mathrm{A})(\mathrm{C}, \mathrm{T}) \mathrm{GT}$ \\
\hline Anabaena variabilis & AvaI & $\mathrm{C} /(\mathrm{C}, \mathrm{T}) \mathrm{CG}(\mathrm{G}, \mathrm{A}) \mathrm{G}$ & M.AvaI & $\mathrm{C} /(\mathrm{C}, \mathrm{T}) \mathrm{CG}(\mathrm{G}, \mathrm{A}) \mathrm{G}^{\mathbf{c}}$ \\
\hline Anabaena variabilis & AvalI & $\mathrm{G} / \mathrm{G}(\mathrm{A}, \mathrm{T}) \mathrm{CC}$ & M.AvalI & $\mathrm{G} / \mathrm{G}(\mathrm{A}, \mathrm{T}) \mathrm{CC}^{\mathrm{d}}$ \\
\hline Anabaena variabilis & AvallI & ATGCAT & M.AvalII & ATGCAT $^{\mathbf{b}}$ \\
\hline Anabaena variabilis uw & $\begin{array}{l}\text { AvrI } \\
\text { (AvaI) }\end{array}$ & $\mathrm{C}(\mathrm{C}, \mathrm{T}) \mathrm{CG}(\mathrm{G}, \mathrm{A}) \mathrm{G}$ & M.AvrI & $\mathrm{C}(\mathrm{C}, \mathrm{T}) \mathrm{CG}(\mathrm{G}, \mathrm{A}) \mathrm{G}^{\mathrm{b}}$ \\
\hline Anabaena variabilis uw & AvrII & C/CTAGG & M.AvrII & CCTAGG $^{\mathbf{b}}$ \\
\hline Arthrobacter citreus & AciI & $\operatorname{CCGC}(-3 /-1)$ & M.AciI & ${ }_{\mathrm{m} 5} \mathrm{CCGC}$ \\
\hline Arthrobacter luteus & AluI & $\mathrm{AG} / \mathrm{CT}$ & M.AluI & $\mathrm{AG} / \mathrm{m} 5 \mathrm{CT}$ \\
\hline Arthrobacter & ApoI & $(\mathrm{G}, \mathrm{A}) \mathrm{AATT}(\mathrm{C}, \mathrm{T})$ & M.ApoI & $(\mathrm{G}, \mathrm{A}) \operatorname{AATT}(\mathrm{C}, \mathrm{T})^{\mathrm{e}}$ \\
\hline
\end{tabular}




\begin{tabular}{|c|c|c|c|c|}
\hline Arthrobacter species & AscI & GG/CGCGCC & M.AscI & $\mathrm{GGCGCGCC}^{\mathbf{d}}$ \\
\hline $\begin{array}{l}\text { Bacillus amyloliquefaciens } \\
\text { F } \\
\text { Bacillus amyloliquefaciens }\end{array}$ & $\begin{array}{l}\mathrm{BamFI}^{\mathrm{a}} \\
(\mathrm{BamHI})\end{array}$ & GGATCC & M.BamFI & $\mathrm{GGAT}_{\mathrm{m} 5 \mathrm{CC}}$ \\
\hline & BamHI & G/GATCC & M.BamHI & $\mathrm{G} / \mathrm{GAT}_{\mathrm{m} 5 \mathrm{CC}}$ \\
\hline $\begin{array}{l}\text { Bacillus amyloliquefaciens } \\
\mathrm{K}\end{array}$ & $\begin{array}{l}\text { BamKI }^{a} \\
(\mathrm{BamHI})\end{array}$ & GGATCC & M.BamKI & $\mathrm{GGAT}_{\mathrm{m} 5 \mathrm{CC}}$ \\
\hline $\begin{array}{l}\text { Bacillus amyloliquefaciens } \\
N\end{array}$ & $\begin{array}{l}\text { BamNI } \\
\text { (Bam HI) }\end{array}$ & GGATCC & M.BamNI & $\mathrm{GGAT}_{\mathrm{m} s \mathrm{CC}}$ \\
\hline Bacillus brevis & $\mathrm{BbvI}$ & $\operatorname{GCAGC}(8 / 12)$ & M.Bbvl & $\mathrm{G}_{\mathrm{m} 5 \mathrm{CAGC}}$ \\
\hline Bacillus brevis $\mathrm{S}$ & BbvSI & $\mathrm{GC}(\mathrm{A}, \mathrm{T}) \mathrm{GC}$ & M.BbvSI & $\mathrm{Gm}_{5} \mathrm{C}(\mathrm{A}, \mathrm{T}) \mathrm{GC}$ \\
\hline Bacillus caldolyticus & BclI & T/GATCA & M.BclI & TGm6ATCA \\
\hline Bacillus coagulans & $\mathrm{BcgI}$ & CGANNNNNNTGC $(12 / 10)$ & M.BcgI & CGm6ANNNNNNTGC \\
\hline Bacillus firmus & Bfil & ACTGGGNNNNN (6 or 7 ) & Ml.Bfil & $\mathrm{Am} 4 \mathrm{CTGGG}$ \\
\hline Bacillus globigii & BglI & GCCNNNN/NGGC & M.BglI & $\mathrm{GC}_{\mathrm{m} 4} \mathrm{CNNNNNGGC}$ \\
\hline Bacillus globigii & BgllI & A/GATCT & M.BglII & $\mathrm{AGAT}_{\mathrm{m} 4 \mathrm{CT}}$ \\
\hline Bacillus smithii & BscGI & CCCGT & M1.BscGI & CCCGT $^{d}$ \\
\hline Bacillus smithii & BscGI & CCCGT & M2.BscGI & $\mathrm{CCCGT}^{\mathrm{d}}$ \\
\hline Bacillus species $\mathrm{H}$ & BspHI & T/CATGA & M.BspHI & TCATGA $^{\mathbf{e}}$ \\
\hline Bacillus species LU11 & BspLU11III & GGGAC (10/14) & M1.BspLU11III & GGGm6AC \\
\hline Bacillus species LU11 & BspLU11III & GGGAC (10/14) & M2.BspLU11III & $3-\mathrm{CC}_{\mathrm{m} 5} \mathrm{CTG}-5$ \\
\hline Bacillus species $M$ & BspMI & ACCTGCNNNN/NNNN & M1.BspMI & $\mathrm{ACCTGC}^{\mathbf{d}}$ \\
\hline Bacillus species $M$ & BspMI & ACCTGCNNNN/NNNN & M2.BspMI & ACCTGC ${ }^{\mathbf{d}}$ \\
\hline Bacillus species $M$ & BspMII & T/CCGGA & M.BspMII & T/CCGGA $^{\mathbf{d}}$ \\
\hline Bacillus species $R$ & BseRI & GAGGAG (10/8) & M.BseRI & GAGGAG $^{\mathbf{b}}$ \\
\hline
\end{tabular}




\begin{tabular}{|c|c|c|c|c|}
\hline Bacillus sphaericus & Bsp1286I & $\mathrm{G}(\mathrm{A}, \mathrm{G}, \mathrm{T}) \mathrm{GC}(\mathrm{A}, \mathrm{C}, \mathrm{T}) / \mathrm{C}$ & M.Bsp1286I & $\mathrm{G}(\mathrm{A}, \mathrm{G}, \mathrm{T}) \mathrm{GC}(\mathrm{A}, \mathrm{C}, \mathrm{T}) / \mathrm{C}^{0}$ \\
\hline $\begin{array}{l}\text { Bacillus sphaericus GC } \\
\text { subgroup }\end{array}$ & BsgI & GTGCAC $(16 / 14)$ & M.BsgI & GTGCAG $^{b}$ \\
\hline $\begin{array}{l}\text { Bacillus sphaericus } \mathrm{R} \\
\text { Bacillus }\end{array}$ & $\begin{array}{l}\text { BspRI }^{a} \\
\text { (HaelII) }\end{array}$ & $\mathrm{GG} / \mathrm{CC}$ & M.BspRI & $\mathrm{GG} / \mathrm{m} 5 \mathrm{CC}$ \\
\hline $\begin{array}{l}\text { stearothermophilus } \\
\text { Bacillus }\end{array}$ & BsaAI & $(\mathrm{C}, \mathrm{T}) \mathrm{AC} / \mathrm{GT}(\mathrm{G}, \mathrm{A})$ & M.BsaAI & 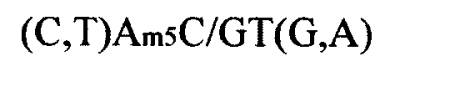 \\
\hline $\begin{array}{l}\text { stearothermophilus } \\
\text { Bacillus }\end{array}$ & BsrBI & $\mathrm{CCG} / \mathrm{CTC}$ & M1.BsrBI & CCGCTC $^{c}$ \\
\hline $\begin{array}{l}\text { stearothermophilus } \\
\text { Bacillus }\end{array}$ & BsrBI & $\mathrm{CCG} / \mathrm{CTC}$ & M2.BsrBI & CCGCTC $^{\mathbf{c}}$ \\
\hline & BsrI & ACTGGN/ & M1.BsrI & ACTGGN $/{ }^{c}$ \\
\hline stearothermophilus & BsrI & ACTGGN/ & M2.BsrII & ACTGGN $/^{c}$ \\
\hline $\begin{array}{l}\text { Bacillus } \\
\text { stearothermophilus } \\
\text { Bacillus }\end{array}$ & $\begin{array}{l}\text { BstNI" } \\
\text { (EcoRII) }\end{array}$ & $\mathrm{CC} /(\mathrm{A}, \mathrm{T}) \mathrm{GG}$ & M.BstNI & $\mathrm{C}_{\mathrm{m}} 4 \mathrm{C}(\mathrm{A}, \mathrm{T}) \mathrm{GG}$ \\
\hline $\begin{array}{l}\text { stearothermophilus } \\
\text { Bacillus }\end{array}$ & BstXI & CCANNNNN/NTGG & M.BstXI & CCANNNNN/NTGG \\
\hline $\begin{array}{l}\text { stearothermophilus 1503- } \\
4 \mathrm{R}\end{array}$ & $\begin{array}{l}\text { BstI }{ }^{\text {a }} \\
\text { (BamHI) }\end{array}$ & G/GATCC & M.BstI & G/Gm6ATCC \\
\hline $\begin{array}{l}\text { Bacillus } \\
\text { stearothermophilus A664 }\end{array}$ & BsmAI & GTCTCN/NNNN & M.BsmAI & GTCTC $^{d}$ \\
\hline $\begin{array}{l}\text { Bacillus } \\
\text { stearothermophilus D70 }\end{array}$ & BsrDI & GCAATGNN/ & M1.BsrDI & GCAATG $^{\mathbf{b}}$ \\
\hline $\begin{array}{l}\text { Bacillus } \\
\text { stearothermophilus D70 }\end{array}$ & BsrDI & GCAATGNN/ & M2.BsrDI & GCAATG $^{\mathbf{b}}$ \\
\hline $\begin{array}{l}\text { Bacillus } \\
\text { stearothermophilus ET }\end{array}$ & BstEII & G/GTNACC & M.BstEII & GGTNACC $^{b}$ \\
\hline
\end{tabular}


Bacillus

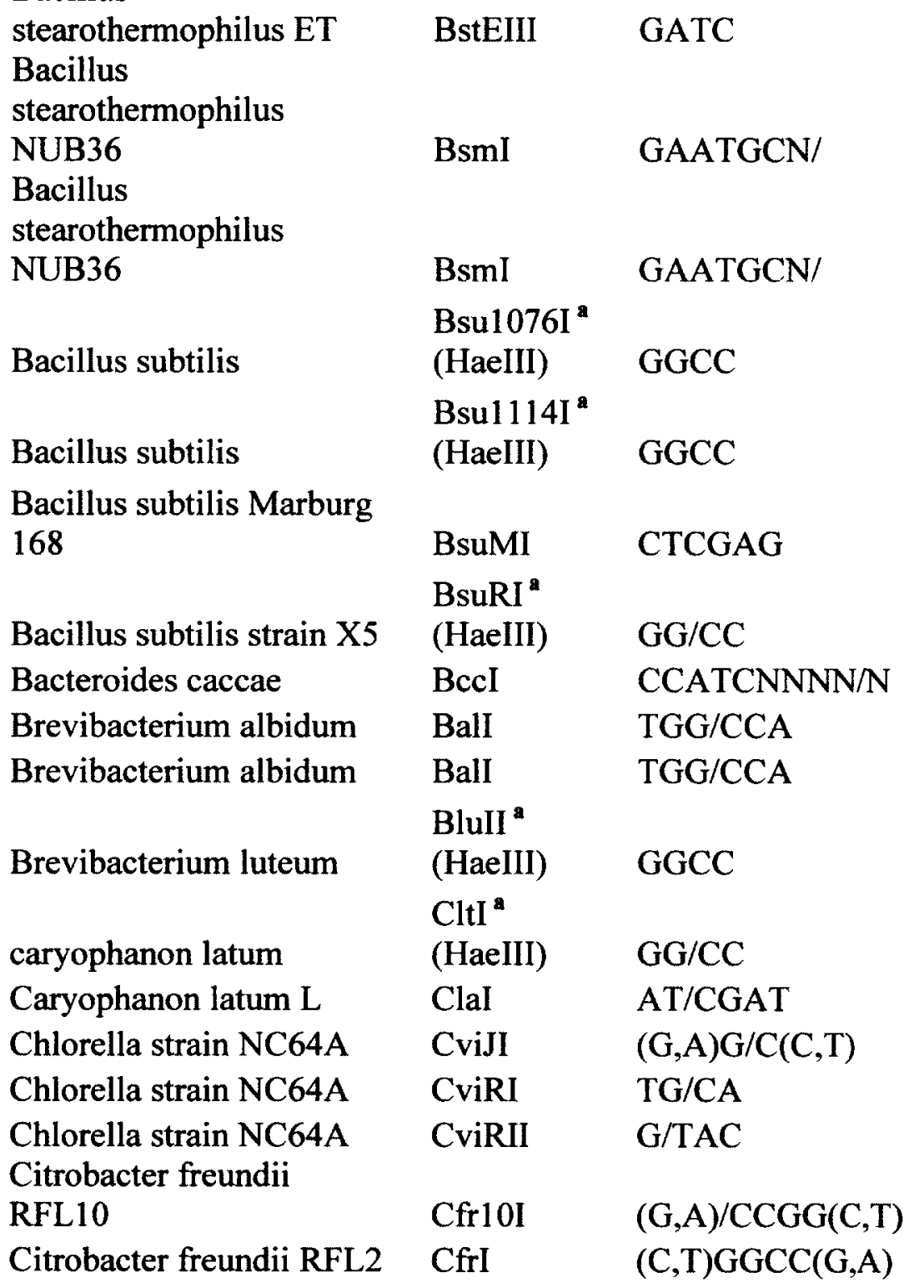

\begin{tabular}{|c|c|}
\hline M.BstEIII & GATC $^{b}$ \\
\hline M1.BsmI & GAATGC $^{b}$ \\
\hline M2.BsmI & GAATGC $^{b}$ \\
\hline M.Bsu1076 & $\mathrm{GG} / \mathrm{m} 5 \mathrm{CC}$ \\
\hline M.Bsu1114 & $\mathrm{GG} / \mathrm{m} 5 \mathrm{CC}$ \\
\hline M.BsuM & $\mathrm{CT}_{\mathrm{m} 5 \mathrm{CGAG}}$ \\
\hline M.BsuRI & $\mathrm{GG} / \mathrm{m} 5 \mathrm{CC}$ \\
\hline M1.BccI & CCATC $^{b}$ \\
\hline M.BaII & TGGCCA $^{c}$ \\
\hline M.Bal I & $\mathrm{TGG} / \mathrm{m} 4 \mathrm{CCA}$ \\
\hline M.BluII & $\mathrm{GG} / \mathrm{m} 5 \mathrm{CC}$ \\
\hline M.Clt I & $\mathrm{GG} / \mathrm{mCC}$ \\
\hline M.Cla 1 & $\mathrm{AT} / \mathrm{CG} 6 \mathrm{AT}$ \\
\hline M.CviJI & $(\mathrm{G}, \mathrm{A}) \mathrm{G} / \mathrm{ms} \mathrm{C}(\mathrm{C}, \mathrm{T})$ \\
\hline M.CviRI & $\mathrm{TGC}_{\mathrm{m} 6 \mathrm{~A}}$ \\
\hline M.CviRII & $\mathrm{GT}_{\mathrm{m} 6 \mathrm{AC}}$ \\
\hline M.Cfr10I & $(\mathrm{G}, \mathrm{A}) / \mathrm{m} 5 \mathrm{CCGG}(\mathrm{C}, \mathrm{T})$ \\
\hline M.CfrI & $(\mathrm{C}, \mathrm{T}) \mathrm{GG}_{\mathrm{m}} \mathrm{CC}(\mathrm{G}, \mathrm{A})$ \\
\hline
\end{tabular}




\begin{tabular}{|c|c|c|c|c|}
\hline $\begin{array}{l}\text { Clostridium } \\
\text { acetobutylicum ABKn8 }\end{array}$ & $\mathrm{Cac} 8 \mathrm{I}$ & GCN/NGC & M.Cac8I & $\mathrm{GCN} / \mathrm{NGC}{ }^{\mathrm{b}}$ \\
\hline $\begin{array}{l}\text { Clostridium } \\
\text { formicoaceticum }\end{array}$ & $\begin{array}{l}\text { Cfol }^{a} \\
\text { (Hhal) }\end{array}$ & $\mathrm{GCG} / \mathrm{C}$ & M.Cfol & $\mathrm{G}_{\mathrm{m} 5 \mathrm{CG} / \mathrm{C}}$ \\
\hline Deinococcus radiophilus & DraII & $(\mathrm{G}, \mathrm{A}) \mathrm{G} / \mathrm{GNCC}(\mathrm{C}, \mathrm{T})$ & M.DraII & $(\mathrm{G}, \mathrm{A}) \mathrm{G} / \mathrm{GNCC}(\mathrm{C}, \mathrm{T})^{\mathbf{b}}$ \\
\hline $\begin{array}{l}\text { Deinococcus radiophilus } \\
\text { Desulfovibrio } \\
\text { desulfuricans Norway }\end{array}$ & DraIII & CACNNN/GTG & M.DraIII & Cm6ACNNN/GTG \\
\hline strain & DdeI & $\mathrm{C} / \mathrm{TNAG}$ & M.DdeI & $\mathrm{m} 5 \mathrm{CTNAG}$ \\
\hline Diplococcus pneumoniae & DpnI & $\mathrm{GA} / \mathrm{TC}$ & M.Dpn I & $\mathrm{G}_{\mathrm{m} 6 \mathrm{ATC}}$ \\
\hline Diplococcus pneumoniae & $\begin{array}{l}\text { DpnII }{ }^{a} \\
\text { (MboI) }\end{array}$ & /GATC & M1.Dpn II & Gm6ATC \\
\hline Diplococcus pneumoniae & $\begin{array}{l}\text { DpnII } \\
\text { (MboI) }\end{array}$ & /GATC & M2.DpnII & $\mathrm{Gm}_{\mathrm{m}} \mathrm{ATC}$ \\
\hline Enterobacter cloacae & $\begin{array}{l}\text { EcaI }^{a} \\
\text { (BstEII) }\end{array}$ & G/GTNACC & M.Ecal & GGTNm6ACC \\
\hline Erwinia species RFL3 & Esp3I & CGTCTCN/NNNN & M.Esp3I & $\mathrm{CGT}_{\mathrm{m} 5 \mathrm{CTC}}$ \\
\hline Escherichia coli & EcoNI & CCTNN/NNNAGG & M.EcoNI & CCTNN/NNNAGG ${ }^{b}$ \\
\hline Escherichia coli (PI) & EcoPI & $\mathrm{AGACC}(25 / 27)$ & M.EcoPI & AGm6ACC \\
\hline Escherichia coli B & EcoBI & TGANNNNNNNNTGCT & M.EcoBI & TGm6ANNNNNNNNTGCT \\
\hline $\begin{array}{l}\text { Escherichia coli J62 } \\
\text { Escherichia coli K }\end{array}$ & EcoRV & GAT/ATC & M.EcoRV & Gm6ATATC \\
\hline MG1655 & EcoKI & AACNNNNNNGTGC & M.EcoKI & Am6ACNNNNNNGTGC \\
\hline Escherichia coli P15 & EcoP15I & CAGCAG $(25 / 27)$ & M.EcoP15I & $\mathrm{CAGC}_{\mathrm{m} 6 \mathrm{~A}}$ \\
\hline Escherichia coli R245 & EcoRII & $\mathrm{CC}(\mathrm{A}, \mathrm{T}) \mathrm{GG}$ & M.EcoRII & $\mathrm{Cm}_{5} \mathrm{C}(\mathrm{A}, \mathrm{T}) \mathrm{GG}$ \\
\hline Escherichia coli RFL31 & $E \operatorname{co} 31 I$ & GGTCTCN/NNNN & M1.Eco31I & 3'-CCm6AGAG-5' \\
\hline Escherichia coli RFL31 & $E \operatorname{co} 311$ & GGTCTCN/NNNN & M2.Eco31I & $\mathrm{GGT}_{\mathrm{m} 5 \mathrm{CTC}}$ \\
\hline Escherichia coli RFL47 & Eco47III & $\mathrm{AGC} / \mathrm{GCT}$ & M.Eco47III & $\mathrm{AGC} / \mathrm{GCT}^{\mathrm{b}}$ \\
\hline Escherichia coli RFL57 & Eco571 & CTGAAGNNNNNNNNNNNNNNNN & M.Eco57I & CTGAm6AG \\
\hline
\end{tabular}




\begin{tabular}{|c|c|c|c|c|}
\hline Escherichia coli RY13 & EcoRI & G/AATTC & M.EcoRI & G/Am6ATTC \\
\hline Flavobacterium aquatile & FauI & CCCGCNNNN/NN & M1.Faul & $\mathrm{C}_{5} 5 \mathrm{CCGC}$ \\
\hline $\begin{array}{l}\text { Flavobacterium } \\
\text { okeanokoites }\end{array}$ & FokI & GGATGNNNNNNNNN/NNNN & M.FokI & GGm6ATG \\
\hline Frankia species Eu11b & Fsel & GGCCGG/CC & M.FseI & GGCCGG/CC ${ }^{\mathbf{d}}$ \\
\hline $\begin{array}{l}\text { Fusobacterium nucleatum } \\
4 \mathrm{H}\end{array}$ & Fnu4HI & GC/NGC & M.Fnu4HI & GCNGC $^{d}$ \\
\hline $\begin{array}{l}\text { Fusobacterium nucleatum } \\
4 \mathrm{H} \\
\text { Fusobacterium nucleatum }\end{array}$ & Fnu4HI & $\mathrm{GC} / \mathrm{NGC}$ & M.Fnu4HI & $\mathrm{GC} / \mathrm{NGC}^{\mathrm{d}}$ \\
\hline $\begin{array}{l}\text { D } \\
\text { Fusobacterium nucleatum }\end{array}$ & FnuDII & $\mathrm{CG} / \mathrm{CG}$ & M.FnuDII & $\mathrm{m} 5 \mathrm{CGCG}$ \\
\hline D & FnuDIII & GCG/C & M.FnuDIII & GCGC $^{\mathbf{b}}$ \\
\hline $\begin{array}{l}\text { Fusobacterium nucleatum } \\
\text { D } \\
\text { Fusobacterium nucleatum }\end{array}$ & $\begin{array}{l}\text { FnuDI } \\
\text { (HaeIII) }\end{array}$ & $\mathrm{GG} / \mathrm{CC}$ & M.FnuDI & $\mathrm{GG} / \mathrm{m} 5 \mathrm{CC}$ \\
\hline $\mathrm{D}$ & FnuDII & $\mathrm{CG} / \mathrm{CG}$ & M.FnuDII & ${ }_{\mathrm{m} 5 \mathrm{CGCG}}$ \\
\hline $\begin{array}{l}\text { Fusobacterium nucleatum } \\
\text { D }\end{array}$ & $\begin{array}{l}\text { FnuDIII } \\
\text { (Hhal) }\end{array}$ & $\mathrm{GCG} / \mathrm{C}$ & M.FnuDIII & $\mathrm{G}_{\mathrm{m} 5 \mathrm{CG} / \mathrm{C}}$ \\
\hline $\begin{array}{l}\text { Gluconobacter suboxydans } \\
\mathrm{H}-15 \mathrm{~T}\end{array}$ & GsuI & CTGGAG $(16 / 14)$ & M.GsuI & CTGGAG $^{\mathbf{b}}$ \\
\hline Haemophilus aegyptius & HaeII & $(\mathrm{G}, \mathrm{A}) \mathrm{GCGC}(\mathrm{C}, \mathrm{T})$ & M.HaelI & $(\mathrm{G}, \mathrm{A}) \mathrm{GCGC}(\mathrm{C}, \mathrm{T}){ }^{\mathbf{d}}$ \\
\hline Haemophilus aegyptius & HaeIII & $\mathrm{GG} / \mathrm{CC}$ & M.HaelII & $\mathrm{GG}_{\mathrm{m} 5 \mathrm{CC}}$ \\
\hline Haemophilus aphrophilus & $\begin{array}{l}\text { HapII } \\
\text { (HpaII) }\end{array}$ & $\mathrm{C} / \mathrm{CGG}$ & M.HapII & $\mathrm{C}_{\mathrm{m} 5 \mathrm{CGG}}$ \\
\hline Haemophilus gallinarum & Hgal & $\operatorname{GACGC}(5 / 10)$ & M1.HgaI & 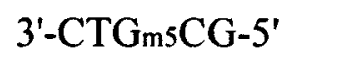 \\
\hline Haemophilus gallinarum & HgaI & $\operatorname{GACGC}(5 / 10)$ & M2.HgaI & GAmsCGC \\
\hline $\begin{array}{l}\text { Haemophilus } \\
\text { haemoglobinophilus }\end{array}$ & $\begin{array}{l}\text { HhgI } \\
\text { (HaelII) }\end{array}$ & GGCC & M.HhgI & $\mathrm{GG} / \mathrm{m} 5 \mathrm{CC}$ \\
\hline
\end{tabular}




\begin{tabular}{|c|c|c|}
\hline Haemophilus haemolyticus & $\begin{array}{l}\text { Hhall }{ }^{*} \\
\text { (Hinfl) }\end{array}$ & GANTC \\
\hline Haemophilus haemolyticus & Hhal & $\mathrm{GCG} / \mathrm{C}$ \\
\hline $\begin{array}{l}\text { Haemophilus influenza } \\
\text { serotype c, } 1160 \\
\text { Haemophilus influenzae }\end{array}$ & $\begin{array}{l}\text { HincIl }^{a} \\
\text { (HindII) }\end{array}$ & $\mathrm{GT}(\mathrm{C}, \mathrm{T})(\mathrm{G}, \mathrm{A}) \mathrm{AC}$ \\
\hline $\begin{array}{l}\text { Rd } \\
\text { Haemophilus influenzae }\end{array}$ & HindII & $\mathrm{GT}(\mathrm{C}, \mathrm{T})(\mathrm{G}, \mathrm{A}) \mathrm{AC}$ \\
\hline $\begin{array}{l}\text { Rd } \\
\text { Haemophilus influenzae }\end{array}$ & HindIII & A/AGCTT \\
\hline $\begin{array}{l}\mathrm{Rf} \\
\text { Haemophilus influenzae }\end{array}$ & HinfI & G/ANTC \\
\hline $\mathrm{Rf}$ & HinflII & CGAAT \\
\hline $\begin{array}{l}\text { Haemophilus } \\
\text { parahaemolyticus }\end{array}$ & HphI & GGTGA $(8 / 7)$ \\
\hline $\begin{array}{l}\text { Haemophilus } \\
\text { parahaemolyticus } \\
\text { Haemophilus }\end{array}$ & $\mathrm{HphI}$ & GGTGA $(8 / 7)$ \\
\hline $\begin{array}{l}\text { parainfluenzae } \\
\text { Haemonhilus }\end{array}$ & Hpal & GTT/AAC \\
\hline parainfluenzae & HpalI & C/CGG \\
\hline $\begin{array}{l}\text { Herpetosiphon giganteus } \\
\text { HP1023 }\end{array}$ & HgiAl & $\mathrm{G}(\mathrm{A}, \mathrm{T}) \mathrm{GC}(\mathrm{A}, \mathrm{T}) \mathrm{C}$ \\
\hline $\begin{array}{l}\text { Herpetosiphon giganteus } \\
\text { Hpa2 }\end{array}$ & HgiDI & $\mathrm{G}(\mathrm{G}, \mathrm{A}) \mathrm{CG}(\mathrm{C}, \mathrm{T}) \mathrm{C}$ \\
\hline $\begin{array}{l}\text { Herpetosiphon giganteus } \\
\text { Hpg } 24\end{array}$ & $\begin{array}{l}\text { HgiEI } \\
\text { (AvaII) }\end{array}$ & $\mathrm{G} / \mathrm{G}(\mathrm{A}, \mathrm{T}) \mathrm{CC}$ \\
\hline $\begin{array}{l}\text { Herpetosiphon giganteus } \\
\text { Hpg } 5\end{array}$ & $\begin{array}{l}\text { HgiBI } \\
\text { (Avall) }\end{array}$ & $\mathrm{G} / \mathrm{G}(\mathrm{A}, \mathrm{T}) \mathrm{CC}$ \\
\hline $\begin{array}{l}\text { Herpetosiphon giganteus } \\
\text { Hpg } 9\end{array}$ & $\begin{array}{l}\text { HgiCII }^{\mathrm{a}} \\
\text { (AvaII) }\end{array}$ & $\mathrm{G} / \mathrm{G}(\mathrm{A}, \mathrm{T}) \mathrm{CC}$ \\
\hline
\end{tabular}

\begin{tabular}{|c|c|}
\hline M.HhaII & $\mathrm{G} / \mathrm{m} 6 \mathrm{ANTC}$ \\
\hline M.HhaI & $\mathrm{G}_{m 5} \mathrm{CGC}$ \\
\hline M.HincII & $\mathrm{GT}(\mathrm{C}, \mathrm{T})(\mathrm{G}, \mathrm{A})_{\mathrm{m} 6 \mathrm{AC}}$ \\
\hline M.HindII & $\mathrm{GT}(\mathrm{C}, \mathrm{T})(\mathrm{G}, \mathrm{A})_{\mathrm{m} 6 \mathrm{AC}}$ \\
\hline M.HindIII & m6AAGCTT \\
\hline M.HinfI & Gm6ANTC \\
\hline M.HinflII & CGAm6AT \\
\hline M1.HphI & 3'-CCAmsCT-5' \\
\hline M2.HphI & GGTGm6A \\
\hline M.HpaI & GTTAm6AC \\
\hline M.Hpall & $\mathrm{Cm}_{\mathrm{m} s \mathrm{CGG}}$ \\
\hline M.HgiAI & $\mathrm{G}(\mathrm{A}, \mathrm{T}) \mathrm{GC}(\mathrm{A}, \mathrm{T}) \mathrm{C}^{\mathrm{b}}$ \\
\hline M.HgiDI & $\mathrm{G}(\mathrm{G}, \mathrm{A}) \mathrm{CG}(\mathrm{C}, \mathrm{T}) \mathrm{C}^{\mathrm{d}}$ \\
\hline M.HgiEI & $\mathrm{G} / \mathrm{G}(\mathrm{A}, \mathrm{T}) \mathrm{CC} \mathrm{C}^{\mathrm{d}}$ \\
\hline M.HgiBI & $\mathrm{G} / \mathrm{G}(\mathrm{A}, \mathrm{T}) \mathrm{CC}^{\mathrm{d}}$ \\
\hline M.HgiCII & $\mathrm{G} / \mathrm{G}(\mathrm{A}, \mathrm{T}) \mathrm{CC}^{\mathrm{d}}$ \\
\hline
\end{tabular}




\begin{tabular}{|c|c|c|c|c|}
\hline $\begin{array}{l}\text { Herpetosiphon giganteus } \\
\text { Hpg9 } \\
\text { Klebsiella pneumoniae }\end{array}$ & HgiCI & $\mathrm{G} / \mathrm{G}(\mathrm{C}, \mathrm{T})(\mathrm{C}, \mathrm{T}) \mathrm{CC}$ & M.HgiCI & $\mathrm{G} / \mathrm{G}(\mathrm{C}, \mathrm{T})(\mathrm{C}, \mathrm{T}) \mathrm{m}_{5} \mathrm{CC}$ \\
\hline $0 \mathrm{~K} 8$ & KpnI & GGTAC/C & M.KpnI & $\mathrm{GGT}_{\mathrm{m} 6 \mathrm{ACC}}$ \\
\hline Maraxella asloensis & Msll & $\mathrm{CA}(\mathrm{C}, \mathrm{T}) \mathrm{NN} / \mathrm{NN}(\mathrm{G}, \mathrm{A}) \mathrm{TG}$ & M.MslI & $\begin{array}{l}\mathrm{CA}(\mathrm{C}, \mathrm{T}) \mathrm{NN} / \mathrm{NN}(\mathrm{G}, \mathrm{A}) \mathrm{TG} \\
\text { (B.U) }\end{array}$ \\
\hline Methanobacterium wolfei & Mwol & GCNNNNN/NNGC & M.Mwol & GCNNNNN/NNGC $^{c}$ \\
\hline $\begin{array}{l}\text { Methylophilus } \\
\text { methylotrophus }\end{array}$ & MmeI & $\mathrm{TCC}(\mathrm{G}, \mathrm{A}) \mathrm{AC}$ & M..MmeI & $\mathrm{TCC}(\mathrm{G}, \mathrm{A}) \mathrm{m} 6 \mathrm{AC}$ \\
\hline $\begin{array}{l}\text { Methylophilus } \\
\text { methylotrophus }\end{array}$ & Mmell & GATC & M.MmeII & GATC $^{b}$ \\
\hline Micrococcus luteus & MluI & A/CGCGT & M.MluI & $\mathrm{ACGCGT}^{\mathbf{c}}$ \\
\hline Micrococcus species & MseI & T/TAA & M.MseI & TTAm6A \\
\hline Moraxella bovis & MboI & GATC & M1.MboI & Gm6ATC \\
\hline Moraxella bovis & Mbol & GATC & M2.MboI & Gm6ATC \\
\hline Moraxella bovis & MbolI & GAAGA $(8 / 7)$ & M1.MbolI & GAAGm6A \\
\hline Moraxella bovis & MboII & GAAGA $(8 / 7)$ & M2.MboII & GAAGA \\
\hline Moraxella nonliquefaciens & $\begin{array}{l}\text { MnnI } \\
\text { (HindII) }\end{array}$ & $\mathrm{GT}(\mathrm{C}, \mathrm{T})(\mathrm{G}, \mathrm{A}) \mathrm{AC}$ & M.MnnI & $\mathrm{GT}(\mathrm{C}, \mathrm{T})(\mathrm{G}, \mathrm{A}) \mathrm{m} 6 \mathrm{AC}$ \\
\hline Moraxella nonliquefaciens & $\begin{array}{l}\text { MnnII }^{\mathrm{a}} \\
\text { (HaeIII) }\end{array}$ & GGCC & M.MnnII & $\mathrm{GG} / \mathrm{m} 5 \mathrm{CC}$ \\
\hline Moraxella nonliquefaciens & $\begin{array}{l}\text { MnnIV } \\
\text { (Hhal) }\end{array}$ & GCGC & M.MnnIV & $\mathrm{Gm} 5 \mathrm{CG} / \mathrm{C}$ \\
\hline Moraxella species & $\begin{array}{l}\mathrm{MspI}^{\mathbf{a}} \\
\text { (HpaII) }\end{array}$ & $\mathrm{C} / \mathrm{CGG}$ & M.MspI & $\mathrm{msC} / \mathrm{CGG}$ \\
\hline Mycoplasma fermentans & MfeI & C/AATTG & M.MfeI & CAATTG $^{\mathbf{e}}$ \\
\hline Neisseria denitrificans & Ndel & $\mathrm{Ca} / \mathrm{TATG}$ & M.NdeI & CATATG $^{\mathbf{e}}$ \\
\hline Neisseria lactamica & NlallI & CATG/ & M.NlaIII & Cm6ATG \\
\hline Neisseria lactamica & NlaIV & GGN/NCC & M.NlaIV & $\mathrm{GGN}^{\mathrm{N}} \mathrm{NCC}{ }^{\mathbf{d}}$ \\
\hline Neisseria mucosa & NheI & G/CTAGC & M.NheI & GCTAGC $^{\mathbf{b}}$ \\
\hline
\end{tabular}




\begin{tabular}{|c|c|c|c|c|}
\hline Nocardia aerocolonigenes & Nael & $\mathrm{GCC} / \mathrm{GGC}$ & M.NaeI & GCCGGC $^{\mathbf{d}}$ \\
\hline Nocardia corallina & Ncol & C/CATGG & M.NcoI & C/CATGG ${ }^{c}$ \\
\hline $\begin{array}{l}\text { Nocardia ottitidis- } \\
\text { caviarum }\end{array}$ & NotI & GC/GGCCGC & M.NotI & $\mathrm{GC} / \mathrm{GGCCGC}^{\mathrm{c}}$ \\
\hline Nocardia rubra & NruI & TCG/CGA & M.NruI & $\mathrm{TCG} / \mathrm{CGA}$ \\
\hline Nostoc species C & NspI & $(\mathrm{G}, \mathrm{A}) \mathrm{CATG} /(\mathrm{C}, \mathrm{T})$ & M.Nspl & $(\mathrm{G}, \mathrm{A})_{\mathrm{m} s} \backslash \mathrm{CATG} /(\mathrm{C}, \mathrm{T})$ \\
\hline $\begin{array}{l}\text { Plesiomonas shigelloides } \\
319-73\end{array}$ & PshAI & GACNN/NNGTC & M.PshAI & Gm6ACNN/NNGTC \\
\hline Proteus vulgaris & Pvul & $\mathrm{CGAT} / \mathrm{CG}$ & M.PuvI & $\mathrm{CGAT} / \mathrm{CG}^{\mathrm{b}}$ \\
\hline Proteus vulgaris & PvulI & $\mathrm{CAG} / \mathrm{CTG}$ & M.PvuII & $\mathrm{CAGm}_{5} \mathrm{CTG}$ \\
\hline Providencia alcalifaciens & Pall & $\mathrm{GG} / \mathrm{CC}$ & M.Pall & $\mathrm{GG} / \mathrm{m} 5 \mathrm{CC}$ \\
\hline Providencia stuartii 164 & PstI & CTGCA/G & M.PstI & $\mathrm{CTGC}_{\mathrm{m} 6 \mathrm{~A}}$ \\
\hline Providencia stuartii 164 & PstI & CTGCA/G & M.PstI & CTGCm6A/G \\
\hline Pseudomonas aeruginosa & PaeR7I & $\mathrm{C} / \mathrm{TCGAG}$ & M.PaeR7 & $\mathrm{C} / \mathrm{TCG} 6 \mathrm{AG}$ \\
\hline Pseudomonas fluorescens & PflMI & CCANNN/NTGG & M.PflMI & CCANNN/NTGG ${ }^{b}$ \\
\hline Pseudomonas lemoignei & PleI & GAGTCNNNN/N & M.PleI & GAGTCNNNN/N ${ }^{b}$ \\
\hline Psudomonas putida $\mathrm{M}$ & PpuMI & $(\mathrm{G}, \mathrm{A}) \mathrm{G} / \mathrm{G}(\mathrm{A}, \mathrm{T}) \mathrm{CC}(\mathrm{C}, \mathrm{T})$ & M.PpuMI & $(\mathrm{G}, \mathrm{A}) \mathrm{G} / \mathrm{G}(\mathrm{A}, \mathrm{T}) \mathrm{CC}(\mathrm{C}, \mathrm{T})^{\mathrm{d}}$ \\
\hline $\begin{array}{l}\text { Rhodopseudomonas } \\
\text { sphaeroides }\end{array}$ & RsaI & GT/AC & M.RsaI & GTAmsC \\
\hline $\begin{array}{l}\text { Rhodopseudomonas } \\
\text { sphaeroides }\end{array}$ & $\begin{array}{l}\mathrm{RshI}^{\mathrm{a}} \\
\text { (PvuI) }\end{array}$ & $\mathrm{CGAT} / \mathrm{CG}$ & M.RshI & $\mathrm{CGAT} / \mathrm{CG}^{\mathbf{d}}$ \\
\hline $\begin{array}{l}\text { Rhodopseudomonas } \\
\text { sphaeroides }\end{array}$ & $\begin{array}{l}\text { RsrI } \\
(\text { EcoRI) }\end{array}$ & G/AATTC & M.RsrI & GAm6ATTC \\
\hline $\begin{array}{l}\text { Rhodopseudomonas } \\
\text { sphaeroides }\end{array}$ & RsrII & $\mathrm{CG} / \mathrm{G}(\mathrm{A}, \mathrm{T}) \mathrm{CCG}$ & M.RsrII & $\mathrm{CG} / \mathrm{G}(\mathrm{A}, \mathrm{T}) \mathrm{CCG}^{\mathrm{d}}$ \\
\hline Saccharopolyspora species & SapI & GCTCTTCN/NNN & M.SapI & GCTCTTCN/NNN ${ }^{b}$ \\
\hline Salmonella typhi 27 & StyI & $\mathrm{C} / \mathrm{C}(\mathrm{A}, \mathrm{T})(\mathrm{A}, \mathrm{T}) \mathrm{GG}$ & M.StyI & $\mathrm{C} / \mathrm{C}(\mathrm{A}, \mathrm{T})(\mathrm{A}, \mathrm{T}) \mathrm{GG}^{\mathbf{b}}$ \\
\hline Serratia marcescens Sb & SmaI & $\mathrm{CCC} / \mathrm{GGG}$ & M.SmaI & $\mathrm{C}_{\mathrm{m} 4 \mathrm{CCGGG}}$ \\
\hline Serratia species SAI & Sspl & AAT/ATT & M.SspI & AATATT $^{e}$ \\
\hline
\end{tabular}




\begin{tabular}{|c|c|c|c|c|}
\hline Sphaerotilus natans & SpeI & A/CTAGT & M.SpeI & A/CTAGT ${ }^{b}$ \\
\hline Sphaerotilus natans & SnaBI & TAC/GTA & M.SnaBI & TAm4CGTA \\
\hline Staphylococcus aureus $3 \mathrm{~A}$ & $\begin{array}{l}\text { Sau3A } \\
\text { (MboI) }\end{array}$ & GATC & M.Sau3A & $\mathrm{GAT}_{\mathrm{m} 5 \mathrm{C}}$ \\
\hline $\begin{array}{l}\text { Staphylococcus aureus } \\
\text { PS96 }\end{array}$ & $\begin{array}{l}\text { Sau96I } \\
\text { (Asul) }\end{array}$ & $\mathrm{G} / \mathrm{GNCC}$ & M.Sau96I & $\mathrm{GGN}_{\mathrm{m} 5 \mathrm{CC}}$ \\
\hline Staphylococcus warneri & SwaI & ATTT/AAAT & M.SwaI & ATTT/AAAT ${ }^{\mathbf{e}}$ \\
\hline Streotomyces caespitosus & ScaI & AGT/ACT & M.ScaI & $\mathrm{AGTAm}_{4} \mathrm{CT}$ \\
\hline Streotomyces exfoliatus & SexAI & $\mathrm{A} / \mathrm{CC}(\mathrm{A}, \mathrm{T}) \mathrm{GGT}$ & M.SexAI & $\mathrm{A} / \mathrm{CC}(\mathrm{A}, \mathrm{T}) \mathrm{GGT}^{\mathrm{d}}$ \\
\hline $\begin{array}{l}\text { Streptococcus cremoris } \\
\text { Streptococcus durans }\end{array}$ & ScrFI & $\mathrm{CC} / \mathrm{NGG}$ & M.ScrFI & $\mathrm{CC} / \mathrm{NGG}^{d}$ \\
\hline RFL3 & SduI & $\mathrm{G}(\mathrm{A}, \mathrm{G}, \mathrm{T}) \mathrm{GC}(\mathrm{A}, \mathrm{C}, \mathrm{T}) / \mathrm{C}$ & M.SduI & $\mathrm{G}(\mathrm{A}, \mathrm{G}, \mathrm{T}) \mathrm{GC}(\mathrm{A}, \mathrm{C}, \mathrm{T}) / \mathrm{C}^{\mathrm{b}}$ \\
\hline Streptococcus faecalis & SfeI & $\mathrm{C} / \mathrm{T}(\mathrm{G}, \mathrm{A})(\mathrm{C}, \mathrm{T}) \mathrm{AG}$ & M.Sfel & $\mathrm{C} / \mathrm{T}(\mathrm{G}, \mathrm{A})(\mathrm{C}, \mathrm{T}) \mathrm{AG}^{\mathrm{b}}$ \\
\hline $\begin{array}{l}\text { Streptococcus faecalis } \\
\text { ND547 }\end{array}$ & SfaNI & GCATCNNNNN/NNNN & M.SfaNI & GCATC $^{b}$ \\
\hline $\begin{array}{l}\text { Streptococcus faecalis var. } \\
\text { Zymogenes }\end{array}$ & $\begin{array}{l}\text { Sfal }^{a} \\
\text { (HaelII) }\end{array}$ & GGCC & M.Sfal & $\mathrm{GG} / \mathrm{m} 5 \mathrm{CC}$ \\
\hline $\begin{array}{l}\text { Streptomyces } \\
\text { achromogenes }\end{array}$ & Sac I & GAGCT/C & M.SacI & $\mathrm{GAG}_{5} \mathrm{CTC}$ \\
\hline $\begin{array}{l}\text { Streptomyces } \\
\text { achromogenes }\end{array}$ & SacII & $\mathrm{CCGC/GG}$ & M.SacII & CCGCGG \\
\hline Streptomyces albus & SalI & G/TCGAC & M.SalI & GTCGm6AC \\
\hline Streptomyces fimbriatus & SfiI & GGCCNNNN/NGGCC & M.SfiI & GGCCNNNN/NGGCC $^{c}$ \\
\hline Streptomyces griseus & SgrAI & $\mathrm{C}(\mathrm{G}, \mathrm{A}) / \mathrm{CCGG}(\mathrm{G}, \mathrm{A}) \mathrm{G}$ & M.SgrAI & $\mathrm{C}(\mathrm{G}, \mathrm{A}) / \mathrm{CCGG}(\mathrm{G}, \mathrm{A}) \mathrm{G}^{\mathbf{d}}$ \\
\hline $\begin{array}{l}\text { Streptomyces } \\
\text { phaeochromogenes }\end{array}$ & SphI & GCATG/C & M.SphI & GCATG/C ${ }^{b}$ \\
\hline Streptomyces stanford & (Sacl) & GAGCT/C & M.SstI & GAGCT/C ${ }^{b}$ \\
\hline Streptomyces tubercidicus & StuI & $\mathrm{AGG} / \mathrm{CCT}$ & M.StuI & $\mathrm{AGG} / \mathrm{CCT}^{\mathrm{b}}$ \\
\hline
\end{tabular}




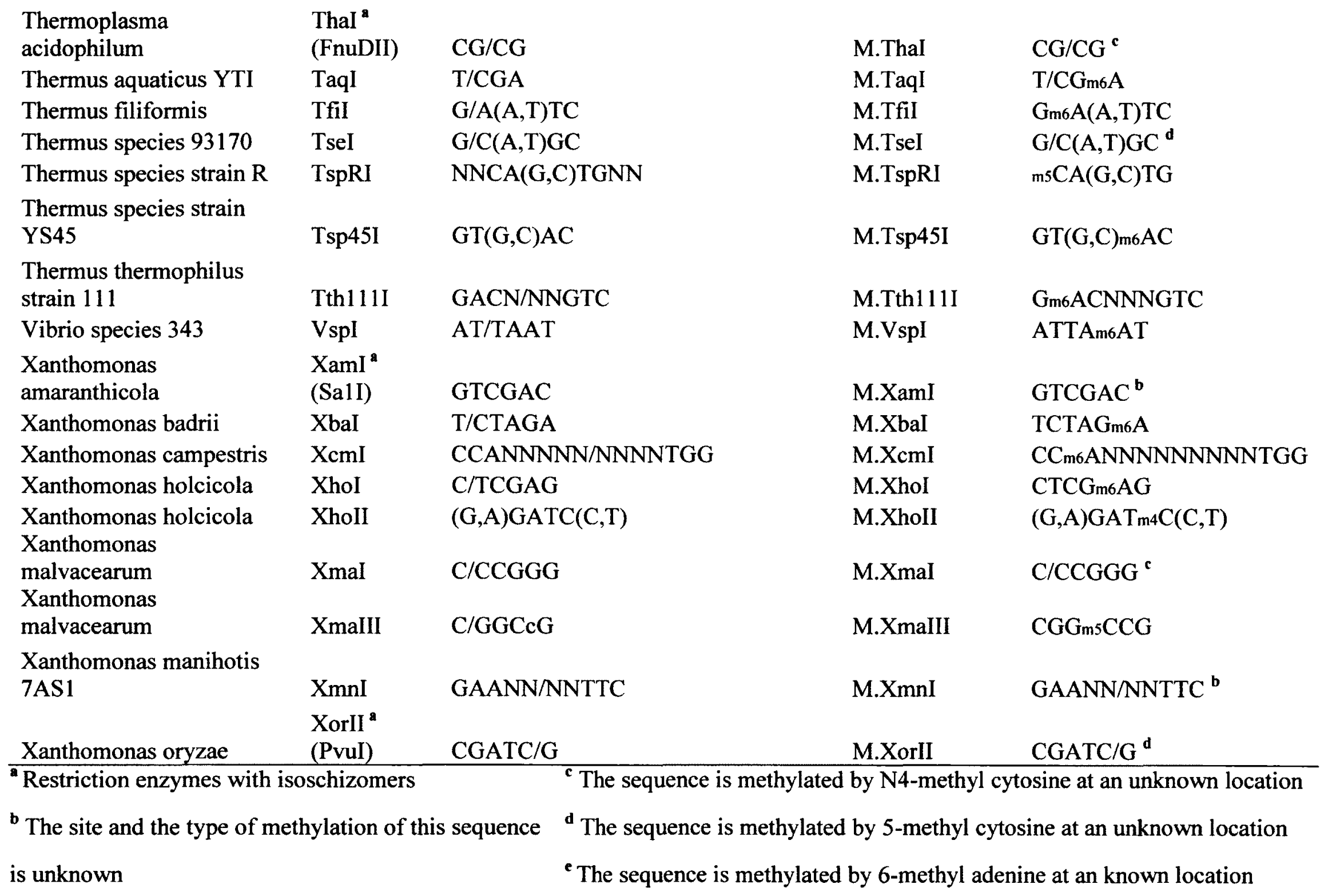


S2. NCBI GenBank accession numbers for 16s rRNA, type II restriction endonuclease restriction enzymes and respective palindrome restriction sites, methylase enzymes and respective methylase sites for all 68 species.

\begin{tabular}{|c|c|c|c|c|c|}
\hline Microorganism & Accession numbers & $\begin{array}{c}\text { Endonuclease } \\
\text { restriction } \\
\text { enzymes }\end{array}$ & $\begin{array}{l}\text { Endonuclease } \\
\text { restriction sites }\end{array}$ & $\begin{array}{l}\text { Methylase } \\
\text { enzymes }\end{array}$ & Methylase sites \\
\hline Acetobacter aceti & D30768.1 & AatII & gacgtc & M.AatII & gacgtc \\
\hline Acetobacter pasteurianus & AY883035.1 & $\begin{array}{l}\text { ApaI } \\
\text { ApaLI }\end{array}$ & $\begin{array}{l}\text { gggecc } \\
\text { gtgcac }\end{array}$ & $\begin{array}{l}\text { M.Apai } \\
\text { M.ApaLI }\end{array}$ & $\begin{array}{l}\text { gggecc } \\
\text { gtgcac }\end{array}$ \\
\hline Acinetobacter calcoaceticus & EU330417.1 & $\begin{array}{l}\text { AccI } \\
\text { AccI } \\
\text { Accl } \\
\text { Accl } \\
\text { AccII } \\
\text { AccIII }\end{array}$ & $\begin{array}{l}\text { gtagac } \\
\text { gtatac } \\
\text { gtcgac } \\
\text { gtctac } \\
\text { aacgtt } \\
\text { tccgga }\end{array}$ & $\begin{array}{l}\text { M.AccI } \\
\text { M.AccI } \\
\text { M.AccI } \\
\text { M.AccI } \\
\text { M.AccII } \\
\text { M.AccIII }\end{array}$ & $\begin{array}{l}\text { gtagac } \\
\text { gtatac } \\
\text { gtcgac } \\
\text { gtctac } \\
\text { aacgtt } \\
\text { tccgga }\end{array}$ \\
\hline $\begin{array}{l}\text { Agrobacterium gelatinovorum } \\
\text { Agrobacterium tumefaciens C } 58\end{array}$ & D88523.1 & $\begin{array}{l}\text { AgeI } \\
\text { AtuCI } \\
\text { AtuCI } \\
\text { AtuCI } \\
\text { AtuCI }\end{array}$ & $\begin{array}{l}\text { accggt } \\
\text { gaatc } \\
\text { gactc } \\
\text { gagtc } \\
\text { gattc }\end{array}$ & $\begin{array}{l}\text { M.Agel } \\
\text { M.AtucI } \\
\text { M.AtucI } \\
\text { M.AtucI } \\
\text { M.AtucI }\end{array}$ & $\begin{array}{l}\text { accggt } \\
\text { gaatc } \\
\text { gactc } \\
\text { gagtc } \\
\text { gattc }\end{array}$ \\
\hline Anabaena flos-aquae & $\mathrm{AB} 042858.1$ & $\begin{array}{l}\text { AflII } \\
\text { AflIII } \\
\text { AflIII } \\
\text { AflIII } \\
\text { AflIII }\end{array}$ & $\begin{array}{l}\text { cttaag } \\
\text { acgcgt } \\
\text { acgtgt } \\
\text { acacgt } \\
\text { acatgt }\end{array}$ & $\begin{array}{l}\text { M.AflII } \\
\text { M.AflIII } \\
\text { M.AflIII } \\
\text { M.AflIII } \\
\text { M.AflIII }\end{array}$ & $\begin{array}{l}\text { cttaag } \\
\text { acgegt } \\
\text { acgtgt } \\
\text { acacgt } \\
\text { acatgt }\end{array}$ \\
\hline Anabaena variabilis & $\mathrm{AB} 016520.1$ & $\begin{array}{l}\text { Aval } \\
\text { Aval } \\
\text { Aval } \\
\text { Aval } \\
\text { AvalI }\end{array}$ & $\begin{array}{l}\text { cccggg } \\
\text { cccgag } \\
\text { ctcggg } \\
\text { ctcgag } \\
\text { ggacc }\end{array}$ & $\begin{array}{l}\text { M.Aval } \\
\text { M.Aval } \\
\text { M.AvaI } \\
\text { M.Aval } \\
\text { M.AvalI }\end{array}$ & $\begin{array}{l}\text { cccggg } \\
\text { cccgag } \\
\text { ctcggg } \\
\text { ctcgag } \\
\text { ggacc }\end{array}$ \\
\hline
\end{tabular}




\begin{tabular}{|c|c|c|c|c|c|}
\hline & & Avall & ggtcc & M.AvalI & ggtcc \\
\hline & & Avalli & atgcat & M.AvalII & atgcat \\
\hline & & AvalVP & gctaagc & M.AvaIVP & gctaagc \\
\hline & & AvalVP & gctcagc & M.AvalVP & gctcagc \\
\hline & & AvalVP & gctgagc & M.AvaIVP & gctgagc \\
\hline & & AvalVP & gettagc & M.AvaIVP & gettagc \\
\hline & & AvalX & $\operatorname{accggc}$ & M.AvaIX & $\operatorname{accggc}$ \\
\hline & & AvalX & gccggc & M.AvalX & gccggc \\
\hline & & AvalX & accggt & M.AvalX & accggt \\
\hline & & AvalX & gccggt & M.AvalX & gccggt \\
\hline Arthrobacter ON14 & AJ810894.1 & AscI & ggcgcgce & M.AscI & ggcgcgcc \\
\hline Arthrobacter protophormiae & AY577525.1 & ApoI & gaattc & M.ApoI & gaattc \\
\hline & & ApoI & gaattt & M.ApoI & gaattt \\
\hline & & ApoI & aaattc & M.ApoI & aaattc \\
\hline & & ApoI & aaattt & M.ApoI & aaattt \\
\hline Bacillus amyloliquefaciens & HM136792.1 & BamFI & ggatcc & M.BamFI & ggatcc \\
\hline Bacillus brevis & $\mathrm{X} 60612.1$ & BbvI & gcagc & M.BbvI & gcagc \\
\hline & & BbvII & gaagac & M.BbvII & gaagac \\
\hline Bacillus caldolyticus & Z26924.1 & BclI & tgatca & M.BclI & tgatca \\
\hline Bacillus coagulans & D16267.1 & BcgI & cgannnnnntgc & M.BcgI & cgannnnnntgc \\
\hline Bacillus firmus & DQ1 18015.1 & Bfil & actggg & M1.Bfil & actggg \\
\hline Bacillus smithii & Z26935.1 & BscGI & $\operatorname{cccgt}$ & M1.BscGI & $\operatorname{cccgt}$ \\
\hline Bacillus subtilis & AB598736.2 & BsuRI & ggcc & M.BsuRI & ggcc \\
\hline & & BsuMI & ctcgag & M.BsuM & ctcgag \\
\hline & & Bsu1076I & ggcc & M.Bsu1076 & ggcc \\
\hline & & Bsu1114I & ggcc & M.Bsu1114 & ggcc \\
\hline Bacteroides caccae & & & & & \\
\hline ATCC43185T & X83951.1 & $\mathrm{BccI}$ & ccatc & M1.BccI & ccatc \\
\hline Caryophanon latum L & X70314.1 & ClaI & atcgat & M.ClaI & atcgat \\
\hline
\end{tabular}




\begin{tabular}{|c|c|c|c|c|c|}
\hline \multirow[t]{8}{*}{ Citrobacter freundii } & \multirow[t]{8}{*}{ HQ399663.1 } & CfrI & cggecg & M.CfrI & cggccg \\
\hline & & CfrI & cggcea & M.CfrI & cggcca \\
\hline & & CfrI & $\operatorname{tggccg}$ & M.Cfrl & $\operatorname{tggccg}$ \\
\hline & & CfrI & tggcca & M.CfrI & tggcca \\
\hline & & Cfr10I & gccggc & M.Cfr10I & gccggc \\
\hline & & CfrioI & gccggt & M.Cfr10I & gecggt \\
\hline & & Cfr10I & $\operatorname{accggc}$ & M.Cfr10I & $\operatorname{accggc}$ \\
\hline & & Cfr10I & accggt & M.Cfr10I & accggt \\
\hline Clostridium formicoaceticum & NR_029267.1 & Cfol & gcgc & M.Cfol & gcgc \\
\hline \multirow[t]{5}{*}{ Deinococcus radiophilus } & \multirow[t]{5}{*}{ NR_026402.1 } & Drall & gggnecc & M.Drall & gggnccc \\
\hline & & Drall & gggncet & M.Drall & gggnect \\
\hline & & DraII & aggnecc & M.DraII & aggnccc \\
\hline & & Drall & aggncet & M.DraII & aggncct \\
\hline & & DrallI & cacnnngtg & M.DralII & cacnnngtg \\
\hline \multicolumn{6}{|l|}{ Desulfovibrio desulfuricans } \\
\hline \multirow[t]{4}{*}{ Norway strain } & \multirow[t]{4}{*}{ HQ591418.1 } & DdeI & ctaag & M.DdeI & ctaag \\
\hline & & DdeI & ctcag & M.DdeI & ctcag \\
\hline & & DdeI & ctgag & M.DdeI & ctgag \\
\hline & & DdeI & cttag & M.DdeI & cttag \\
\hline \multirow[t]{4}{*}{ Enterobacter cloacae } & \multirow[t]{4}{*}{ HM585374.1 } & EcaI & ggtaacc & M.EcaI & ggtaacc \\
\hline & & EcaI & ggtcacc & M.EcaI & ggtcacc \\
\hline & & Ecal & ggtgacc & M.Ecal & ggtgacc \\
\hline & & EcaI & ggttacc & M.EcaI & ggttacc \\
\hline Erwinia toletana & FR870447.1 & Esp3I & cgtctc & M.Esp3I & cgtctc \\
\hline Flavobacterium aquatile & AB517711.1 & Faul & $\operatorname{cccgc}$ & M1.FauI & $\operatorname{cccgc}$ \\
\hline Flavobacterium okeanokoites & D55729.1 & FokI & ggatg & M.FokI & ggatg \\
\hline \multirow[t]{3}{*}{ Fusobacterium nucleatum } & \multirow[t]{3}{*}{ AF543300.1 } & Fnu4HI & gcagc & M.Fnu4HI & gcagc \\
\hline & & Fnu4HI & $\operatorname{gccgc}$ & M.Fnu4HI & $\operatorname{gccgc}$ \\
\hline & & Fnu4HI & $\operatorname{gcggc}$ & M.Fnu4HI & gcggc \\
\hline
\end{tabular}




\begin{tabular}{|c|c|c|c|c|c|}
\hline & & Fnu4HI & gctgc & M.Fnu4HI & gctgc \\
\hline & & FnuDII & $\operatorname{cgcg}$ & M.FnuDII & $\operatorname{cgcg}$ \\
\hline & & FnuDIII & gcgc & M.FnuDIII & gcgc \\
\hline Gluconobacter oxydans & AB308275.1 & Gsul & ctggag & M.GsuI & ctggag \\
\hline \multirow[t]{5}{*}{ Haemophilus aegyptius } & M75044.1 & HaeII & ggcgcc & M.HaeII & ggcgcc \\
\hline & & HaeII & ggcget & M.Haell & ggcget \\
\hline & & HaeII & agcgcc & M.Haell & agcgcc \\
\hline & & HaeII & agcgct & M.Haell & agcgct \\
\hline & & HaellI & ggcc & M.HaeIII & ggcc \\
\hline $\begin{array}{l}\text { Haemophilus aphrophilus } \\
\text { Haemophilus }\end{array}$ & M75041 & HapII & $\operatorname{ccgg}$ & M.HapII & ccgg \\
\hline haemoglobinophilus & M75064.1 & HhgI & ggcc & M.HhgI & ggcc \\
\hline \multirow[t]{5}{*}{ Haemophilus haemolyticus } & M75045 & Hhal & gcgc & M.HhaI & $\operatorname{gcgc}$ \\
\hline & & Hhall & gaatc & M.HhaII & gaatc \\
\hline & & Hhall & gactc & M.Hhall & gactc \\
\hline & & HhaII & gagtc & M.HhaII & gagtc \\
\hline & & Hhall & gattc & M.Hhall & gattc \\
\hline \multirow[t]{4}{*}{ Haemophilus influenzae } & AY360336.1 & HinclI & gtcgac & M.HinclI & gtcgac \\
\hline & & HincII & gtcaac & M.Hincll & gtcaac \\
\hline & & HincII & gttgac & M.HinclI & gttgac \\
\hline & & HincII & gttaac & M.HinclI & gttaac \\
\hline Haemophilus parahaemolyticus & M75073.1 & HphI & ggtga & M1.HphI & ccact \\
\hline \multirow[t]{2}{*}{ Haemophilus parainfluenzae } & M75081.1 & Hpal & gttaac & M.HpaI & gttaac \\
\hline & & HpalI & $\operatorname{ccgg}$ & M.HpaII & $\operatorname{ccgg}$ \\
\hline Methanothermobacter wolfei & AB104858.1 & Mwol & gcnnnnnnngc & M.MwoI & gcnnnnnnngc \\
\hline \multirow[t]{3}{*}{ Methylophilus methylotrophus } & AB193724.1 & MmeI & tccgac & M..MmeI & tccgac \\
\hline & & MmeI & tccaac & M..MmeI & tccaac \\
\hline & & MmeII & gatc & M.Mmell & gatc \\
\hline Micrococcus luteus & EF154262.1 & MluI & acgcgt & M.MluI & acgcgt \\
\hline
\end{tabular}




\begin{tabular}{|c|c|c|c|c|c|}
\hline Micrococcus species CCGE3063 & EU867326.1 & Msel & ttaa & M.MseI & $\operatorname{ttaa}$ \\
\hline \multirow[t]{2}{*}{ Moraxella bovis } & AF005183.1 & Mbol & gatc & M1.MboI & gatc \\
\hline & & MboII & gaaga & M1.MboII & gaaga \\
\hline \multirow[t]{6}{*}{ Moraxella nonliquefaciens } & AF005181.1 & MnnI & gtcgac & M.MnnI & gtcgac \\
\hline & & MnnI & gtcaac & M.MnnI & gtcaac \\
\hline & & MnnI & gttgac & M.MnnI & gttgac \\
\hline & & MnnI & gttaac & M.MnnI & gttaac \\
\hline & & MnnII & ggcc & M.MnnII & ggcc \\
\hline & & MnnIV & $\operatorname{gcgc}$ & M.MnnIV & $\operatorname{gcgc}$ \\
\hline Moraxella species 0408225 & HM037355.1 & MspI & $\operatorname{ccgg}$ & M.MspI & $\operatorname{ccgg}$ \\
\hline Mycoplasma fermentans & $\mathrm{AB} 069812.1$ & MfeI & caattg & M.MfeI & caattg \\
\hline Neisseria denitrificans & L06173.1 & NdeI & catatg & M.Ndel & catatg \\
\hline \multirow[t]{2}{*}{ Neisseria lactamica } & $\mathrm{AJ} 247242.2$ & NlaIV & ggnncc & M.NlaIV & ggnncc \\
\hline & & NlaIII & catg & M.NlaIII & catg \\
\hline Neisseria mucosa & AJ247260.2 & NheI & gctagc & M.Nhel & gctagc \\
\hline Plesiomonas shigelloides $319-73$ & DQ822762.1 & PshAI & gacnnnngtc & M.PshAI & gacnnnngtc \\
\hline \multirow[t]{2}{*}{ Proteus vulgaris } & HM446044.1 & PvuI & cgatcg & M.PuvI & cgatcg \\
\hline & & PvuII & cagctg & M.PvulI & cagctg \\
\hline Providencia alcalifaciens & AY994312.1 & Pall & ggcc & M.Pall & ggcc \\
\hline Providencia stuartii 164 & HM216181.1 & PstI & ctgcag & M.PstI & ctgca \\
\hline Pseudomonas aeruginosa & JF827020.1 & PaeR7I & ctcgag & M.PaeR7 & ctcgag \\
\hline Pseudomonas fluorescens & HQ141340.1 & PfIMI & ccannnntgg & M.PflMI & ccannnntgg \\
\hline \multirow[t]{5}{*}{ Rhodopseudomonas sphaeroides } & DQ915852.1 & Rsal & gtac & M.RsaI & gtac \\
\hline & & RshI & cgatcg & M.RshI & cgatcg \\
\hline & & RsrI & gaattc & M.RsrI & gaattc \\
\hline & & Rsrll & cggaccg & M.RsrII & cggaccg \\
\hline & & Rsrll & cggtccg & M.RsrII & cggtccg \\
\hline \multicolumn{6}{|l|}{ Saccharopolyspora Hirsutastrain } \\
\hline ATCC 2787 & U93341.1 & SapI & getcttc & M.SapI & getcttc \\
\hline
\end{tabular}




\begin{tabular}{|c|c|c|c|c|c|}
\hline Serratia marcescens & FN563489.2 & SmaI & cccggg & M.SmaI & cccggg \\
\hline \multirow[t]{2}{*}{ Sphaerotilus natans } & $\mathrm{AB} 072236.2$ & SnaBI & tacgta & M.SnaBI & tacgta \\
\hline & & SpeI & actagt & M.SpeI & actagt \\
\hline Staphylococcus warneri & DQ007519.1 & SwaI & atttaaat & M.Swal & atttaaat \\
\hline Streotomyces caespitosus & $\mathrm{AB} 184320.2$ & Scal & agtact & M.Scal & agtact \\
\hline \multirow[t]{4}{*}{ Streptococcus cremoris } & M58836.1 & ScrFI & ccagg & M.ScrFI & ccagg \\
\hline & & ScrFI & $\operatorname{cccgg}$ & M.ScrFI & $\operatorname{cccgg}$ \\
\hline & & ScrFI & ccggg & M.ScrFI & ccggg \\
\hline & & ScrFI & $\operatorname{cctgg}$ & M.ScrFI & $\operatorname{cctgg}$ \\
\hline Streptomyces albus & EF059751.1 & SalI & gtcgac & M.SalI & gtcgac \\
\hline Streptomyces fimbriatus & $\mathrm{AB} 045868.1$ & Sfil & ggccnnnnnggcc & M.SfiI & ggccnnnnnggcc \\
\hline \multirow[t]{4}{*}{ Streptomyces griseus } & EF154278.1 & SgrAI & cgccgggg & M.SgrAI & cgccgggg \\
\hline & & SgrAI & cgccggag & M.SgrAI & cgccggag \\
\hline & & SgrAI & caccgggg & M.SgrAI & caccgggg \\
\hline & & SgrAI & caccggag & M.SgrAI & caccggag \\
\hline $\begin{array}{l}\text { Streptomyces } \\
\text { phaeochromogenes }\end{array}$ & AF500071.1 & SphI & gcatgc & M.SphI & gcatgc \\
\hline Thermoplasma acidophilum & M38637.1 & ThaI & $\operatorname{cgcg}$ & M.Thal & $\operatorname{cgcg}$ \\
\hline Thermus aquaticus & EU682501.1 & TaqI & tcga & M.TaqI & tcga \\
\hline \multirow[t]{2}{*}{ Thermus filiformis } & L09667.1 & Tfil & gaatc & M.Tfil & gaatc \\
\hline & & TfiI & gattc & M.Tfil & gattc \\
\hline Xanthomonas campestris & EF059753.1 & $\mathrm{Xcml}$ & ccannnnnnnnntgg & $\mathrm{M} . \mathrm{XcmI}$ & ccannnnnnnnntgg \\
\hline Xanthomonas oryzae & X95921.1 & XorII & cgatcg & M.XorII & cgatcg \\
\hline
\end{tabular}


S3. Number of endonuclease restriction sequences, number of methylase sequences, and number of overlapping sequences of 96 type II restriction endonuclease enzymes and 96 corresponding methylase enzymes in 68 microbial species.

\begin{tabular}{|c|c|c|c|c|c|c|c|}
\hline Microorganisms & $\begin{array}{l}\text { Endonuclease } \\
\text { restriction } \\
\text { enzymes }\end{array}$ & $\begin{array}{l}\text { Endonuclease } \\
\text { restriction sites }\end{array}$ & $\begin{array}{l}\text { Number of } \\
\text { endonucleas } \\
\text { e restriction } \\
\text { sites }\end{array}$ & $\begin{array}{l}\text { Methylase } \\
\text { enzymes }\end{array}$ & Methylase sites & $\begin{array}{l}\text { Number } \\
\text { of } \\
\text { methylas } \\
\text { e sites }\end{array}$ & $\begin{array}{c}\text { Number of } \\
\text { overlaps }\end{array}$ \\
\hline pasteurianus & ApaI & gggecc & 1 & M.Apai & Gggecc & 1 & 1 \\
\hline & ApaLI & gtgcac & 0 & M.ApaLI & Gtgcac & 0 & 0 \\
\hline \multirow{5}{*}{$\begin{array}{l}\text { Acinetobacter } \\
\text { calcoaceticus }\end{array}$} & AccI & gtatac & 0 & M.AccI & Gtatac & 0 & 0 \\
\hline & AccI & gtcgac & 0 & M.AccI & Gtcgac & 0 & 0 \\
\hline & AccI & gtctac & 0 & M.AccI & Gtctac & 0 & 0 \\
\hline & AccII & aacgtt & 0 & M.AccII & Aacgtt & 0 & 0 \\
\hline & AccIII & tccgga & 0 & M.AccIII & Tccgga & 0 & 0 \\
\hline \multirow{3}{*}{$\begin{array}{l}\text { Agrobacterium } \\
\text { gelatinovorum } \\
\text { Agrobacterium } \\
\text { tumefaciens C58 }\end{array}$} & AgeI & accggt & 0 & M.AgeI & Accggt & 0 & 0 \\
\hline & AtuCI & gagtc & 0 & M.AtucI & Gagtc & 0 & 0 \\
\hline & AtuCI & gattc & 0 & M.AtucI & Gattc & 0 & 0 \\
\hline \multirow[t]{5}{*}{ Anabaena flos-aquae } & AflII & cttaag & 0 & M.AflII & Cttaag & 0 & 0 \\
\hline & AflIII & acgcgt & 1 & M.AflIII & Acgcgt & 1 & 1 \\
\hline & AflIII & acgtgt & 0 & M.AflIII & Acgtgt & 0 & 0 \\
\hline & AflIII & acacgt & 1 & M.AflIII & Acacgt & 1 & 1 \\
\hline & AflIII & acatgt & 0 & M.AflIII & Acatgt & 0 & 0 \\
\hline \multirow[t]{3}{*}{ Anabaena variabilis } & Aval & cccggg & 1 & M.Aval & Cccggg & 1 & 1 \\
\hline & Aval & cccgag & 1 & M.Aval & Cccgag & 1 & 1 \\
\hline & Aval & ctcggg & 0 & M.Aval & Ctcggg & 0 & 0 \\
\hline
\end{tabular}




\begin{tabular}{|c|c|c|c|c|c|c|}
\hline & AvaI & ctcgag & 0 & M.Aval & Ctcgag & 0 \\
\hline & Avall & ggacc & 0 & M.Avall & Ggacc & 0 \\
\hline & Avall & ggtcc & 0 & M.AvalI & Ggtcc & 0 \\
\hline & AvallI & atgcat & 0 & M.AvallI & Atgcat & 0 \\
\hline & AvalVP & gctaagc & 0 & M.AvaIVP & Gctaagc & 0 \\
\hline & AvalVP & gctcagc & 0 & M.AvaIVP & Gctcagc & 0 \\
\hline & AvalVP & getgagc & 0 & M.AvalVP & Gctgagc & 0 \\
\hline & AvalVP & gcttagc & 0 & M.AvaIVP & Gcttagc & 0 \\
\hline & AvaIX & $\operatorname{accggc}$ & 0 & M.AvalX & Accggc & 0 \\
\hline & AvalX & gccggc & 0 & M.AvaIX & Gecggc & 0 \\
\hline & AvalX & accggt & 1 & M.AvaIX & Accggt & 1 \\
\hline & AvaIX & gccggt & 1 & M.AvalX & Gccggt & 1 \\
\hline Arthrobacter ON14 & AscI & ggcgcgce & 0 & M.AscI & Ggcgcgce & 0 \\
\hline Arthrobacter & & & & & & \\
\hline protophormiae & Apol & gaattc & 1 & M.ApoI & Gaattc & 1 \\
\hline & ApoI & gaattt & 0 & M.ApoI & Gaattt & 0 \\
\hline & ApoI & aaattc & 0 & M.ApoI & Aaattc & 0 \\
\hline & ApoI & aaattt & 0 & M.ApoI & Aaattt & 0 \\
\hline Bacillus & & & & & & \\
\hline $\begin{array}{l}\text { amyloliquefaciens } \\
\text { Bacillus brevis }\end{array}$ & $\begin{array}{l}\text { BamFl } \\
\text { BbvI }\end{array}$ & $\begin{array}{l}\text { ggatcc } \\
\text { gcagc }\end{array}$ & $\begin{array}{l}0 \\
3\end{array}$ & $\begin{array}{l}\text { M.BamFI } \\
\text { M.BbvI }\end{array}$ & $\begin{array}{l}\text { Ggatcc } \\
\text { Gcagc }\end{array}$ & $\begin{array}{l}0 \\
3\end{array}$ \\
\hline & BbvII & gaagac & 0 & M.BbvII & Gaagac & 0 \\
\hline Bacillus caldolyticus & Bcll & tgatca & 0 & M.BclI & Tgatca & 0 \\
\hline Bacillus coagulans & Bcgl & cgannnnnntgc & 0 & M.Bcgl & cgannnnnntgc & 0 \\
\hline Bacillus firmus & Bfil & actggg & 2 & M1.Bfil & Actggg & 2 \\
\hline Bacillus smithii & BscGI & $\operatorname{cccgt}$ & 1 & M1.BscGI & Cccgt & 1 \\
\hline Bacillus subtilis & BsuRI & ggcc & 4 & M.BsuRI & Ggec & 4 \\
\hline & BsuMI & ctcgag & 0 & $\begin{array}{l}\text { M.BsuM } \\
\text { M.Bsu107 }\end{array}$ & Ctcgag & 0 \\
\hline & Bsu1076I & ggce & 4 & $\begin{array}{l}6 \\
\text { M.Bsul11 }\end{array}$ & Ggec & 4 \\
\hline & Bsul114I & $\operatorname{ggcc}$ & 4 & 4 & Ggcc & 4 \\
\hline Bacteroides caccae & BccI & ccatc & 0 & M1.BccI & ccatc & 0 \\
\hline
\end{tabular}


ATCC43185T

Caryophanon latum

L

Citrobacter freundii

Clal

CfrI

CfrI

CfrI

CfrI

Cfr10I

Cfr10I

Cfr10I

Cfr 10I

Clostridium

formicoaceticum

Deinococcus

radiophilus

Desulfovibrio

desulfuricans

Norway strain

Enterobacter cloacae

Ddel

Ddel

DdeI

DdeI

Ecal

Ecal

EcaI

Ecal

Erwinia toletana

Flavobacterium

aquatile

Flavobacterium
Esp3I

Faul

FokI atcgat

cggecg

cggcca

tggccg

tggeca

gccgge

gccggt

accggc

accggt

$\operatorname{gcgc}$

gggnecc

gggncet

aggnccc

aggncet

cacnnngtg

ctaag

ctcag

ctgag

cttag

ggtaacc

ggtcacc

ggtgacc

ggttacc

cgtctc

cccgc

ggatg
M.ClaI

M.CfrI

M.CfrI

M.CfrI

M.CfrI

M.Cfr10I

M.Cfr10I

M.Cfr10I

M.Cfr10I

Atcgat

Cggecg

Cggeca

Tggccg

Tggeca

Gccgge

Gccggt

Accggc

Accggt

M.CfoI Gcgc

M.Drall Gggnecc

M.Drall Gggnect

M.Drall Aggncec

M.DralI

M.DraIII

Aggncet

Cacnnngtg

M.Ddel

M.DdeI

M.DdeI

M.DdeI

M.Ecal

M.Ecal

M.Ecal

M.Ecal

M.Esp3I

Ctaag

Ctcag

Ctgag

Cttag

Ggtaacc

Ggtcacc

Ggtgace

Ggttacc

Cgtctc

M1.Faul

M.FokI

Cccgc

ggatg
1

0

0

0

0

0

1

2

1

0

1

0

2 
okeanokoites

Fusobacterium

\begin{abstract}
nucleatum
\end{abstract}

$\begin{array}{ll}\text { Fnu4HI } & \text { gcagc } \\ \text { Fnu4HI } & \text { gccgc } \\ \text { Fnu4HI } & \text { gcggc } \\ \text { Fnu4HI } & \text { gctgc } \\ \text { FnuDII } & \text { cgcg } \\ \text { FnuDIII } & \text { gcgc }\end{array}$

M.Fnu4HI

M.Fnu4HI

Gcagc

MFnu4HI

M.Fnu4HI Getgc

M.FnuDII Cgcg

Gluconobacter

suboxydan H15T

Gsul

ctggag

M.FnuDIII

Gcge

M.GsuI Ctggag

HaelI

ggcgec

aegyptius

HaeII

ggcget

HaeII

agcgcc

HaelI

agcget

HaelII

ggcc

Haemophilus

aphrophilus

Haemophilus

haemoglobinophilus

HapII

$\operatorname{ccgg}$

HhgI

ggce

HhaI

haemolyticus

HhalI

HhaII

Hhall

HhaII

Haemophilus

influenza

Hincll

HinclI

HinclI

HinclI

gcge

gaatc

gactc

gagtc

gattc

Haemophilus

parahaemolyticus

HphI

gtcgac

gtcaac

gttgac

gttaac

M.HaeII Ggcgcc

M.HaeII Ggcget

M.HaeII Agcgcc

M.HaeII Agcget

M.HaeIII Ggcc

6

M.HapII

Ccgg

M.HhgI

Ggec

M.HhaI

M.HhalI

Gcge

M.HhaII

M.Hhall

Gaatc

Gactc

M.HhaII

Gagtc

Gattc

M.HincII

Gtcgac

M.HincII

M.HincII

M.HincII

Gtcaac

Gttgac

Gttaac

M1.HphI

Ccact

4

4 


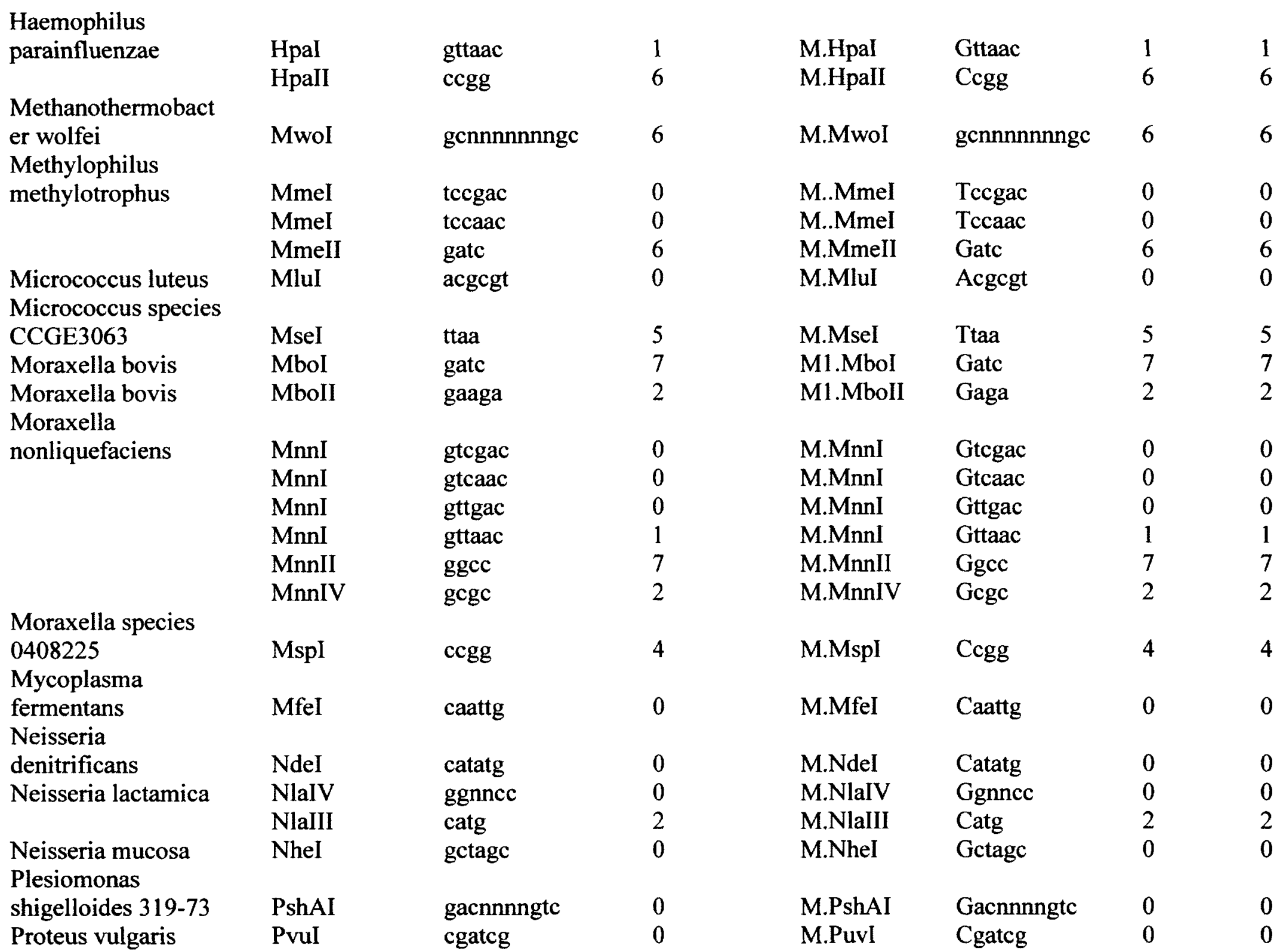




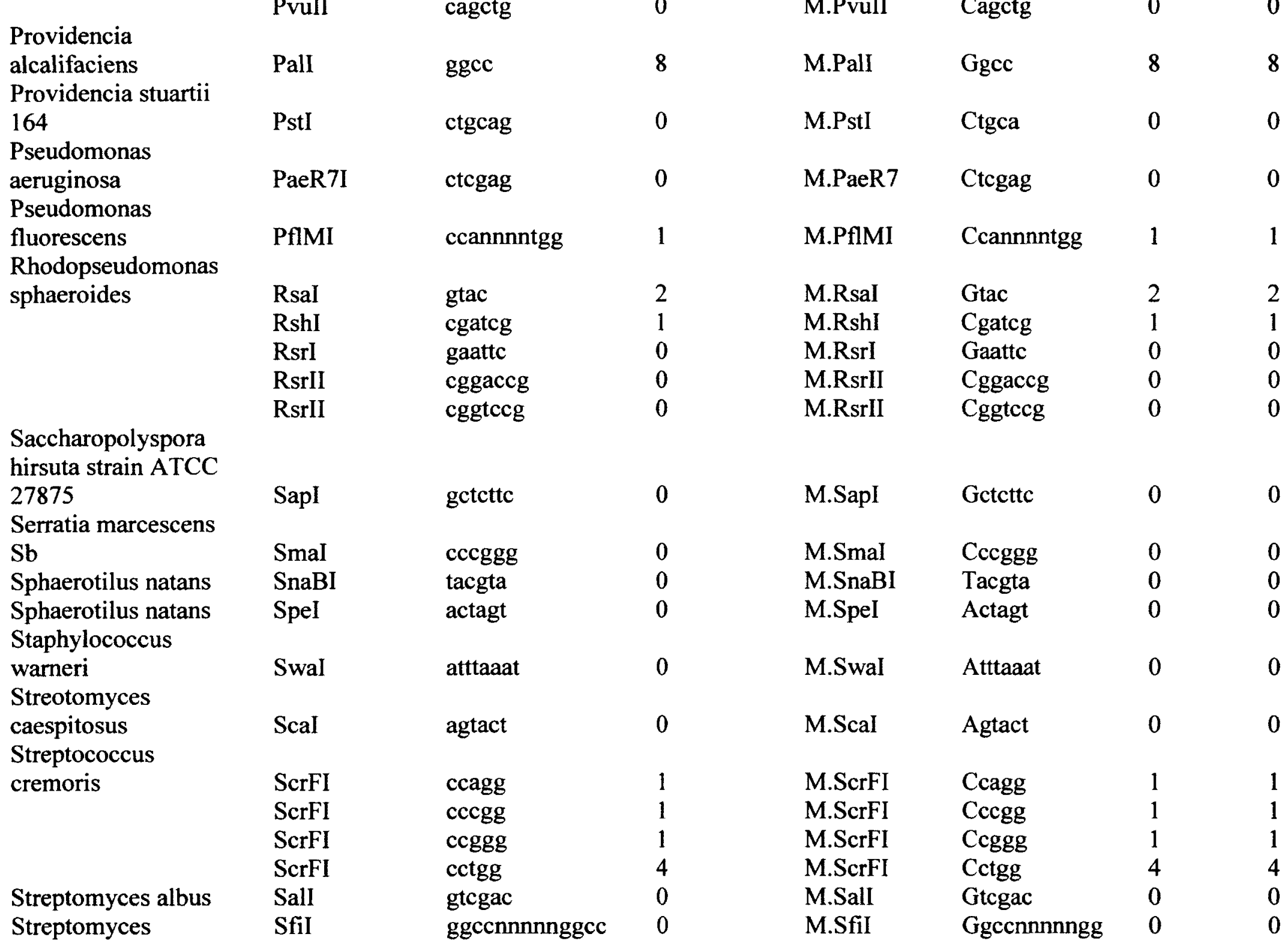


fimbriatus

Streptomyces

griseus

$\begin{array}{lll}\text { griseus } & \begin{array}{l}\text { SgrAI } \\ \text { SgrAI }\end{array} & \begin{array}{l}\text { cgccgggg } \\ \text { cgccggag } \\ \text { caccgggg } \\ \text { caccggag }\end{array} \\ \begin{array}{l}\text { SgrAI } \\ \begin{array}{l}\text { Streptomyces } \\ \text { phaeochromogenes }\end{array}\end{array} & \text { SphI } & \text { gcatgc } \\ \begin{array}{l}\text { Thermoplasma } \\ \text { acidophilum }\end{array} & \text { ThaI } & \text { cgcg } \\ \begin{array}{l}\text { Thermus aquaticus } \\ \text { Thermus filiformis }\end{array} & \text { TaqI } & \text { tcga } \\ & \text { TfiI } & \text { gaatc } \\ \text { Xanthomonas } & \text { Tfil } & \text { gattc } \\ \text { campestris } & & \text { gcannnnnnnt } \\ \text { Xanthom } & \text { Xcm } & \text { gg }\end{array}$

Xanthomonas oryzae XorII

*16S rRNA was used for the sequence analysis for the 68 microbial species. cc

$\begin{array}{lll}\text { Cgccgggg } & 0 & 0 \\ \text { Cgccggag } & 0 & 0 \\ \text { Caccgggg } & 0 & 0 \\ \text { Caccggag } & 0 & 0 \\ \text { Gcatgc } & 1 & 1 \\ \text { Cgcg } & 9 & 9 \\ \text { Tcga } & 3 & 3 \\ \text { Gaatc } & 3 & 3 \\ \text { Gattc } & 0 & 0 \\ \text { Ccannnnnnnn } & & \\ \text { ntgg } & 1 & 1 \\ \text { Cgatcg } & 0 & 0\end{array}$




\section{R codes used for the statistical analysis:}

\section{1) Pagel's lambda phylogenetic signal analysis in $R:$}

library(geiger)

library(picante)

require(phytools)

\# Insert the data file in csv format into $\mathrm{R}$

data<-read.csv("C://Users//Sanoji//Desktop//Thesis Defense (MSc.)//16S_GLS_40taxa.csv",header=T)

$\operatorname{attach}($ data)

data

row.names(data)<-data\$Species

\# Insert the maximum likelihood tree (nwk format) created in MEGA with using CLUSTALW alignments to $\mathrm{R}$

tree $<-$

read.tree(text=" $((()((()(((($ Haemophilus_aegyptius:0.02834477,Haemophilus_haemolyticus:0.00952275)0.4940:0.00674721,Haemo philus_haemoglobinophilus:0.03542718)0.3160:0.00169733,Haemophilus_aphrophilus:0.03221469)0.5660:0.00481971,Haemophilus parahaemolyticus:0.03345315)0.8100:0.00255476,Haemophilus_parainfluenzae:0.02651519)1.0000:0.05286736,(Providencia_alcali faciens:0.04001225,(Citrobacter_freundii:0.00874124,Enterobacter_cloacae:0.01983125)0.9980:0.01917691)0.9820:0.02297715)0.98 20:0.04481612,(Moraxella_species_0408225:0.05260118,(Moraxella_bovis:0.01587325,Moraxella_nonliquefaciens:0.01472209)0.90 
20:0.01772407)1.0000:0.05090132)0.2620:0.00297452,(Neisseria_lactamica:0.10389168,(Methylophilus_methylotrophus:0.0803166 5,Rhodopseudomonas_sphaeroides:0.04893634)0.6700:0.00000000)0.6280:0.05862459)0.3200:0.01042517,Pseudomonas_fluorescen s:0.09245554)0.2760:0.00379425,Xanthomonas_campestris:0.08262809)0.9440:0.03326924,(Gluconobacter_oxydans:0.02920671,(A cetobacter_aceti:0.01032713,Acetobacter_pasteurianus:0.02256529)1.0000:0.01477971)0.9880:0.08186815)0.5520:0.02233481,Desu Ifovibrio_desulfuricans_Norway_strain:0.14228055)0.6660:0.00989726,(Deinococcus_radiophilus:0.11931439,Thermus_filiformis:0. 12747435)0.9980:0.07595853)0.5040:0.01470060,(((Arthrobacter_protophormiae:0.02984946,Micrococcus_species_CCGE3063:0.02 582441)1.0000:0.03548763,Streptomyces_phaeochromogenes:0.05837572)1.0000:0.07145076,((Flavobacterium_aquatile:0.2844353 3,Fusobacterium_nucleatum:0.18525005)0.4820:0.01088731,(Clostridium_formicoaceticum:0.12262417,(Streptococcus_cremoris:0.1 2663599,(Bacillus_brevis:0.05004504,(Thermus_aquaticus:0.05950836,(Bacillus_smithii:0.03143985,(Bacillus_subtilis:0.04230718,( Bacillus_firmus:0.01828016,Flavobacterium_okeanokoites:0.04248660)0.4980:0.00061841)0.9660:0.00925016)0.8800:0.01551923)0 $.9540: 0 . \overline{0} 1482449) 0.9580: 0.02399982) 0.6440: 0.00887582) 0.8320: 0.03543660) 0.3120: 0.00000000) 0.4820: 0.00213549) 0.4800: 0.0590$ 6264,(Anabaena_flos_aquae:0.01952297,Anabaena_variabilis:0.04446831)0.9400:0.05265282,(Methanothermobacter_wolfei:0.1313 2052,Thermoplasma_acidophilum:0.21142217)1.0000:0.40041443);")

\# Root the tree in order to do GLS

tree\$root.edge $<-0$

names(EN_Sites)<-rownames(data)

names(M_Sites)<-rownames(data)

tree $2<-$ multi2di(tree,random $=\mathrm{T}$ )

plot(tree2) 
\#testing for phylogenetic signal using Blomberg's $\mathrm{K}$ :

signal<-phylosignal(EN_Sites,tree2)

signal

signal<-phylosignal(M_Sites,tree2)

signal

\#testing for phylogenetic signal using Pagel's Lambda:

phylosig(tree,EN_Sites,method="lambda",test=TRUE)

phylosig(tree,M_Sites,method="lambda",test=TRUE)

\# This calculates Pagel's lambda for the actual tree

fitContinuous(tree2, data\$EN_Sites, model= "lambda")

fitContinuous(tree2, data\$M_Sites, model= "lambda") 
\# This creates a new, "null" tree with uninformative branch lengths

phy0 <- lambdaTree $($ tree, 0$)$

plot(phy0)

\# Run the code on the new null tree

fitContinuous(phy0, data\$EN_Sites,model= "lambda")

fitContinuous(phy0, data\$M_Sites, model= "lambda")

2) Quantitative sequence comparison of endonuclease restriction sequences with the methyltransferase sequences using Seqinr and Ape packages in R:

\# Install and load the "ape" and "seqRFLP" packages

\#install.packages("ape")

library(ape)

\#install.packages("seqRFLP")

library(seqRFLP)

\# Read in the data from a comma-separated file

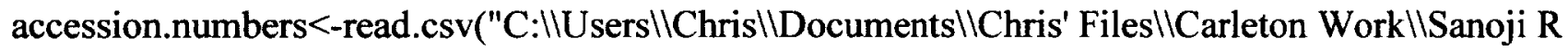
stuff $\backslash$ Datasheet.csv",header=TRUE)

\# Attach this data file to the workspace 
attach(accession.numbers)

\# Define the colummn of accession numbers as "character" format

accession<-as.character(Accession)

E.results.sp<-factor(0)

E.results.enzyme<-character $(0)$

E.results.site $<$-character $(0)$

E.results.loc $<$-numeric(0)

M.results.sp<-character(0)

M.results.enzyme<-character(0)

M.results.site<-character(0)

M.results.loc<-numeric(0)

\# Define the first column as the species names from the GenBank query

species $<$-unique(Microorganism)

\# Start a loop for each sequences (each species)

for( $\mathrm{x}$ in 1 :length(species $))\{$

for $(\mathrm{y}$ in 1:length(subset(Microorganism,Microorganism=-species $[\mathrm{x}])))\{$

\# reading DNA from accession numbers individually 
genes<-read.GenBank(subset(Accession,Microorganism==species[x])[y], species.names $=$ TRUE,gene.names $=$ TRUE, as.character $=$ TRUE)

gene.seq<-paste(genes[[1]],sep="',collapse="")

\# DNA sequence comes from the accession number, the probe is defined as the site associated with that gene and enzyme

e.locations<-findprobe(gene.seq,as.character(subset(ERS,Microorganism=-species[x])[y]),tol=0)

m.locations<-findprobe(gene.seq,as.character(subset(MRS,Microorganism==species $[\mathrm{x}])[\mathrm{y}]$ ), tol=0)

E.results.sp<-as.character(c(E.results.sp,as.character(rep(species[x],length(e.locations)))))

E.results.enzyme<-

as.character(c(E.results.enzyme,as.character(rep(subset(E.enzymes,Microorganism $=$ species[x])[y],length(e.locations)))))

E.results.site<-as.character(c(E.results.site,as.character(rep(subset(ERS,Microorganism==species[x])[y],length(e.locations)))))

E.results.loc<-c(E.results.loc,e.locations)

M.results.sp<-as.character(c(M.results.sp,as.character(rep(species[x],length(m.locations)))))

M.results.enzyme<-

as.character(c(M.results.enzyme,as.character(rep(subset(M.enzymes,Microorganism==species[x])[y],length(m.locations)))))

M.results.site<-as.character(c(M.results.site,as.character(rep(subset(MRS,Microorganism==species[x])[y],length(m.locations)))))

M.results.loc<-c(M.results.loc,m.locations)

\}

\}

E.results.sp<-E.results.sp[-1] 
\# Set up two results tables with the first column as a list of species, the second column as a list of enzymes, the third column as a list of binding sites and the fourth column as a list of locations

E.results $<$-matrix(ncol=4,nrow=length(E.results.sp))

M.results<-matrix(ncol=4,nrow=length(M.results.sp))

\# Name the columns

colnames(E.results)<-c("Species","E.Enzyme","Sites","Locations")

colnames(M.results)<-c("Species","M.Enzyme","Sites","Locations")

\# Paste vectors into the appropriate columns

E.results[,1]<-as.character(E.results.sp)

E.results[,2]<-as.character(E.results.enzyme)

E.results[,3]<-as.character(E.results.site)

E.results[,4]<-as.numeric(E.results.loc)

M.results[,1]<-as.character(M.results.sp)

M.results[,2]<-as.character(M.results.enzyme)

M.results[,3]<-as.character(M.results.site)

M.results[,4]<-as.numeric(M.results.loc)

E.results<-unique(E.results)

M.results<-unique(M.results) 
E.final.results $<-$ matrix (ncol=4,nrow=nrow(unique(E.results[,c(1:3)])))

colnames(E.final.results)<-c("Species","EN enzyme","EN site","EN locations")

E.final.results[,1]<-unique(E.results[,c(1:3)])[,1]

E.final.results[,2]<-unique(E.results[,c(1:3)])[,2]

E.final.results[,3]<-unique(E.results[,c(1:3)])[,3]

for(x in $1: \operatorname{nrow}($ unique(E.results[,c(1:3)]))) \{

E.final.results[x,4]<-length(subset(as.numeric(E.results[,4]),E.results[,1] $=$ E.final.results[x,1] \& E.results[,2] $==$ E.final.results[x,2] \& E.results[,3]==E.final.results[x,3] \& as.numeric(E.results[,4])>0))

\}

M.final.results<-matrix(ncol=4,nrow=nrow(unique(M.results[,c(1:3)])))

colnames(M.final.results)<-c("Species","M enzyme","M site","M locations")

M.final.results[,1]<-unique(M.results[,c(1:3)])[,1]

M.final.results[,2]<-unique(M.results[,c(1:3)])[,2]

M.final.results[,3]<-unique(M.results[,c(1:3)])[,3]

for(x in 1:nrow(unique(M.results[,c(1:3)]))) \{

M.final.results[x,4]<-length(subset(as.numeric(M.results[,4]),M.results[,1]==M.final.results[x,1] \& M.results[,2]=-M.final.results[x,2] \& M.results[,3]==M.final.results[x,3] \& as.numeric(M.results[,4])>0))

\}

write.table(E.final.results, "C:\Users $\backslash$ Chris $\backslash D o c u m e n t s \ \backslash C h r i s '$ Files $\backslash C$ Carleton Work $\backslash S$ Sanoji R stuff $\backslash E N$ final results.txt") 
write.table(M.final.results,"C: \Users $\backslash$ Chris $\backslash$ Documents $\backslash C h r i s '$ Files $\| C$ arleton Work $\backslash$ Sanoji R stuff $\mid M$ final results.txt")

\# Calculating the overlap between sequences.

\# First, checking what the locations mean:

test.seq<-"ABCDEFGHIJKLMNOP"

probe<-"FGHI"

findprobe(test.seq,probe,tol $=0$ )

\# Location=6, so

\# A B C D E F GH I K L M N OP

\# $12345 \mathrm{~F} \mathrm{G} \mathrm{H} \mathrm{I}$

for( $\mathrm{x}$ in $1: 2)\{$ \#length(species $))\{$

E.sites<-as.numeric(subset(E.results[,4],E.results[,1]==species[x]))

M.sites<-as.numeric(subset(M.results[,4],M.results[,1] $=$ species[x]))

site.comparison<-matrix(ncol=3,nrow=length(E.sites)*length(M.sites))

site.comparison[,1]<-rep(E.sites,length(M.sites))

site.comparison.data<-numeric $($ length $=0)$

for(y in 1:length(M.sites))\{

site.comparison.data<-c(site.comparison.data,rep(M.sites[y],length(E.sites)))

\} 
site.comparison[,1]<-site.comparison.data

\}

for(y in 1:length(site.comparison[,1]))\{

site.comparison[y,3]<-site.comparison[y,1]-site.comparison[y,2]

\}

table(site.comparison[y,3]<nchar(

\}

write.table(results,"C: $\|$ Users $\backslash|C h r i s| \backslash D o c u m e n t s \mid \backslash C h r i s '$ Files $\| C$ arleton Work $\|$ Sanoji R stuffloverlap results.txt",header=TRUE) 


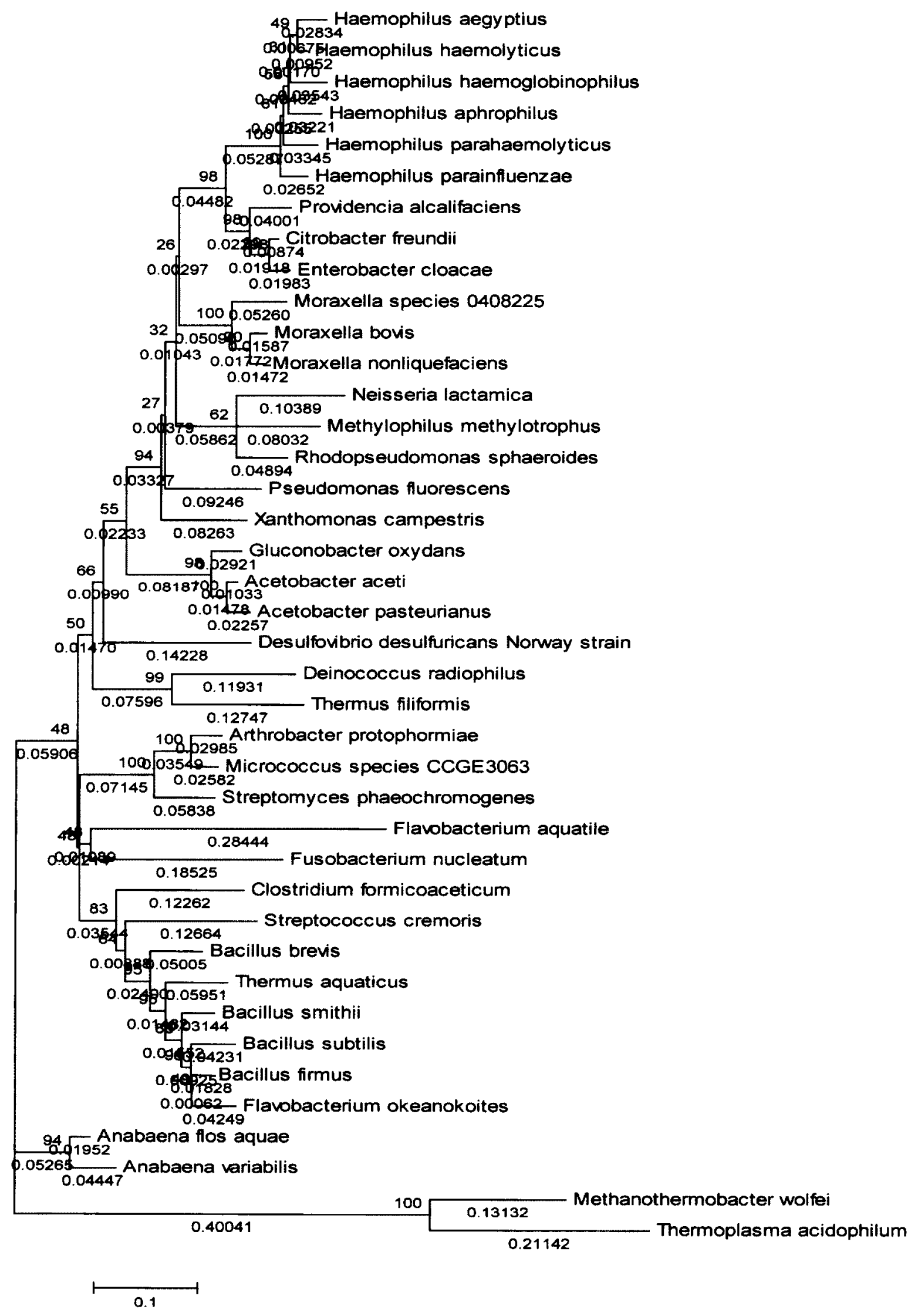


Figure 4. Molecular phylogeny of 38 eubacterial and 2 archaea species based on complete and partial $16 \mathrm{~S}$ rRNA. The tree was constructed in MEGA 2.02 with the maximum likelihood method and 500 bootstrap intervals. The branch lengths correspond to a scale of 0.05 . 